\title{
POZAUSTAWODAWCZE PROCEDURY PARLAMENTARNE W PIERWSZYM SEJMIE ODRODZONEJ RZECZYPOSPOLITEJ POLSKIEJ (1919-1922). REGULACJA PRAWNA I PRAKTYKA PARLAMENTARNA
}

\section{EXTRA-LEGISLATIVE PARLIAMENTARY PROCEDURES IN THE FIRST SEJM OF THE RENASCENT REPUBLIC OF POLAND (1919-1922). LEGAL REGULATIONS AND PARLIAMENTARY PRACTICE}

The first Sejm of the Renascent Republic of Poland — the Legislative Sejm — performed not only the legislative function, but also other systemic functions: oversight over the executive, creative function and the function of the guardian of Deputies' immunity. In order to perform those functions, the chamber applied various detailed parliamentary procedures - variants of the so-called motion proceedings. The sources of law of these procedures contained norms rudimentarily included in the Small Constitution of 20 February 1919 and principally, in the Standing Orders of the Sejm, although there predominated legal-customary norms, partially implemented from Western European parliamentarism, and partially established domestically, on the basis of parliamentary practice. The majority of extra-legislative procedures and proceedings commenced on their basis, were those within the oversight function of the Sejm (including proceedings related to government investments, interpellations and proceedings involving investigative committees), and further, proceedings related to immunity, including mostly proceedings in matters to express the chamber's consent to waive a Deputy's immunity and interventions related to infringement of a Deputy's immunity by organs of administration. The proceedings established by the Legislative Sejm in relation to immunity proceedings, in the scope of bringing Deputies to extra-immunity accountability, applied eight times before the intra-chamber peer courts - Marshal's Court and Court of Honour - were an originality in all of the European parliamentarism of the time.

Słowa kluczowe: exposé premiera, funkcja kontrolna, funkcja kreacyjna, immunitet poselski, inwestytura rządu, komisje sejmowe, komisje śledcze, konstytuanta, mała konstytucja z 1919 r., marszałek Sejmu, organy Sejmu, poseł sprawozdawca, postępowania okołoimmunitetowe, postępowania interpelacyjne, praktyka parlamentarna, procedura parlamentarna, prawo pozytywne, prawo zwyczajowe, rząd koalicyjny, rząd pozaparlamentarny, sąd honorowy, sąd marszałkowski, Tymczasowy Regulamin Obrad Sejmu Ustawodawczego, wniosek poselski, wotum nieufności, wotum zaufania, zwyczaj parlamentarny, źródła prawa

Key words: Prime Minister's exposé, oversight function, creative function, Deputies' immunity, government investment, Sejm committees, investigative committees, constituent assembly, Small Constitution of 1919, Marshal of the Sejm, organs of the Sejm, Deputy-Rapporteur, immunity proceedings, interpellation proceedings, parliamentary practice, parliamentary procedure, positive law, custom law, coalition government, extra-parliamentary government, court of honour, Marshals' court, Provisional Rules of Procedure of the Legislative Sejm, Deputy's motion, vote of no confidence, vote of confidence, parliamentary custom, sources of law

* Dr hab. Piotr A. Tusiński, prof. w Instytucie Prawa, Administracji i Ekonomii Uniwersytetu Pedagogicznego im. KEN w Krakowie, ptusinski@up.krakow.pl, https://orcid.org/0000-0002-4430-0967 


\section{WPROWADZENIE}

D ierwszy parlament odrodzonej Rzeczypospolitej Polskiej - Sejm Ustawodawczy [dalej: SU] pełnił obok wiodącej funkcji ustawodawczej kilka innych ról ustrojowych, z których najistotniejszymi były kompetencje kontrolna i kreacyjna ${ }^{1}$. W obrębie każdej z tych funkcji ustrojowych Sejm działał w ramach określonej procedury parlamentarnej (trybu postępowania) rozumianej jako regulowany normami prawa i zwyczajami zbiór czynności, układających się w sukcesywny (etapowy) łańcuch decyzyjny, podejmowanych wyłącznie przez podmioty wskazane normami kompetencyjnymi, w kolejności wyznaczonej normami formalnymi i organizacyjnymi, prowadzący do załatwienia (rozstrzygnięcia) jakiejś sprawy mieszczącej się w uprawnieniach parlamentu ${ }^{2}$. Kształt procedur parlamentarnych stosowanych w SU w latach 1919-1922 był regulowany aktami normatywnymi rangi konstytucyjnej, ustawami zwykłymi, aktem wewnętrznego prawa parlamentarnego - regulaminem sejmowym oraz normami prawa zwyczajowego.

W ramach funkcji kontrolnej egzekutywy SU stosował procedury stricte kontrolne, takie jak postępowanie: w sprawie inwestytury rządu, w sprawie votum zaufania dla rządu lub votum nieufności dla rządu i Naczelnika Państwa, interpelacyjne, z udziałem komisji śledczej oraz procedury łączące w sobie elementy postępowania kontrolnego sensu stricto z elementami postępowania ustawodawczego, do których można zaliczyć: procedurę wyrażania zgody na ratyfikację umów międzynarodowych i procedurę zatwierdzania ustawodawstwa dekretowego stanowionego przez egzekutywę. Dwie ostatnie z wymienionych procedur miały więcej cech charakterystycznych dla postępowania ustawodawczego niż kontrolnego, stąd opisano je w innym miejscu ${ }^{3}$. W obrębie funkcji kreacyjnej konstytuanta stosowała procedury wyłaniania obsady personalnej jej organów wewnętrznych: marszałka, wicemarszałków, sekretarzy izby (odnoszące się także do przyjęcia ich rezygnacji bądź odwołania), kwestorów, składu osobowego komisji sejmowych, a także wyboru osób do składu niektórych organów państwowych. SU stosował też inne procedury szczególne niemieszczące się w ramach trzech wymienionych wcześniej funkcji ustrojowych parlamentu. Do grupy tych procedur należy zaliczyć postępowania w szeroko rozumianych sprawach immunitetowych (okołoimmunitetowych): ważności mandatu poselskiego, wyrażenia zgody na uchylenie immunitetu poselskiego (formalnego), interwencji w zakresie naruszenia nietykalności poselskiej przez organy administracji, a także egzekwowania odpowiedzialności pozaimmunitetowej posłów.

${ }^{1}$ Confer B. Banaszak, Prawo konstytucyjne, Warszawa 2012, s. 435-438.

2 Vide m.in. Stownik języka polskiego, t. II, L-P, Warszawa 1979, s. 926; E. Kustra, Proces ustawodawczy jako proces decyzyjny, „Acta Universitatis Nicolai Copernici. Prawo XII. Nauki Humanistyczno-Społeczne" 1973, z. 56, s. 110; P.A. Tusiński, Postępowanie ustawodawcze w Sejmie i w Senacie II Rzeczypospolitej 1919-1939. Prawo - zwyczaje - praktyka parlamentarna, Radom 2008, s. 25.

3 Vide P.A. Tusiński, Procedury ustawodawcze w pierwszym Sejmie Odrodzonej Rzeczypospolitej Polskiej (1919-1922). Regulacja prawna i praktyka parlamentarna, „Przegląd Sejmowy” 2018, nr 6. 


\section{KONSTYTUCYJNE I USTAWOWE ŹRÓDLA PRAWA PROCEDUR KONTROLI RZĄDU}

W okresie bezpośrednio poprzedzającym zebranie się SU oraz w czasie jego kadencji obowiązywały trzy akty prawne pełniące rolę prowizorycznej (tymczasowej) konstytucji. Wszystkie one zawierały przepisy odnoszące się do szeroko rozumianej materialnej i formalnej kontroli rządu. Pierwszym był wydany przez Radę Regencyjną dekret z dnia 3 stycznia 1918 r. o tymczasowej organizacji władz naczelnych w Królestwie Polskim 4 . Drugim ustanowiony przez Radę Ministrów i Tymczasowego Naczelnika Państwa dekret z dnia 22 listopada 1918 r. o najwyższej władzy reprezentacyjnej Republiki Polskiej. Trzecim zaś uchwalona przez SU tzw. mała konstytucja z 20 lutego $1919 \mathrm{r}^{6}$

Dekret z 3 stycznia 1918 r. o tymczasowej organizacji władz naczelnych w Królestwie Polskim miał fundamentalne znaczenie dla kształtu ustrojowego rządu do czasu wejścia w życie konstytucji z 17 marca 1921 r. ${ }^{7}$, a częściowo — w odniesieniu do podstawy prawnej działalności wielu ministerstw — zachowywał aktualność nawet do końca międzywojnia. Dekret powierzał władzę zwierzchnią w Królestwie Radzie Regencyjnej [dalej: RR], która miała ją sprawować za pośrednictwem prezydenta Ministrów (premiera), Rady Ministrów oraz poszczególnych ministrów. Wszelkie akty RR musiały być kontrasygnowane przez prezydenta Ministrów. Dekret z 3 stycznia 1918 r. nie określał ani podmiotu powołującego prezydenta Ministrów, ani trybu, w jakim miało się to dokonywać. W literaturze historycznoprawnej zauważono, że kompetencja do powoływania premiera przysługiwała Radzie Regencyjnej ,z samej istoty jako tymczasowej głowie państwa". Dekret stanowił natomiast wprost, że RR powoływała na wniosek prezydenta Ministrów poszczególnych ministrów, podsekretarzy stanu, dyrektorów departamentów i kancelarii oraz prezesów rad działających poza strukturą ministerstw.

W odniesieniu do egzekutywy i jej kontroli dekret z dnia 22 listopada 1918 r. o najwyższej władzy reprezentacyjnej Republiki Polskiej utrzymywał w mocy zasadnicze zręby prawne konstrukcji ustrojowej określone w stosownym akcie Rady Regencyjnej z 3 stycznia $1918 \mathrm{r}$. W dalszym ciągu władza wykonawcza miała charakter dwuczłonowy, a rząd tworzyli mianowani przez naczelnika i przed nim odpowiedzialni prezydent Ministrów i ministrowie, łączący się w Radę Ministrów (art. 1-3, art. 6). W dekrecie z 22 listopada 1918 r. zabrakło tylko, obecnego w akcie z 3 stycznia 1918 r., postanowienia o powoływaniu ministrów na wniosek premiera. Akty rządowe głowy państwa nadal miały być kontrasygnowane przez szefa rządu (art. 4). Nowością w porównaniu

${ }^{4}$ Dziennik Praw Królestwa Polskiego [dalej: Dz.P.K.P.] z 1918 r. nr 1, poz. 1. Treść dekretu omówił W. Komarnicki, Polskie prawo polityczne (Geneza i system), Warszawa 1922, s. 44-47.

${ }^{5}$ Dziennik Praw Państwa Polskiego [dalej: Dz.P.P.P.] z 1918 r. nr 17 poz. 41.

${ }^{6}$ Uchwała Sejmu z dnia 20 lutego 1919 r. o powierzeniu Józefowi Piłsudskiemu dalszego sprawowania urzędu Naczelnika Państwa, Dz.P.P.P. nr 19 poz. 226.

7 Ustawa z dnia 17 marca 1921 r. Konstytucja Rzeczypospolitej Polskiej, Dz.U. nr 44, poz. 267.

${ }^{8}$ Z.J. Winnicki, Rada Regencyjna Królestwa Polskiego i jej organy (1917-1918), Wrocław 1991, s. 73. Vide M.M. Lipska, Urząd ministra w latach 1918-1939. Podstawy prawne, „Roczniki Nauk Prawnych" 2009, t. XIX, nr 1, s. 222. 
z poprzednim stanem prawnym była jurydyzacja odpowiedzialności politycznej ministrów, którzy mieli ją ponosić, obok premiera, przed Tymczasowym Naczelnikiem Państwa, choć dekret listopadowy nie określał wyraźnie charakteru tej odpowiedzialności (art. 2)9.

Uchwalona przez SU 20 lutego 1919 r. mała konstytucja była w odniesieniu do kwestii kontroli rządu aktem równie zwięzłym regulacyjnie, jak dekret z 22 listopada 1918 r. W jej artykule pierwszym konstytuanta podziękowała Józefowi Piłsudskiemu ze sprawowania przezeń urzędu głowy państwa w okresie od 14 listopada 1918 r. do 20 lutego 1919 r. W artykule drugim powierzyła mu zaś dalsze sprawowanie urzędu Naczelnika Państwa do czasu uchwalenia przepisów stałej konstytucji, określających ustrój naczelnych władz państwowych. Można zatem stwierdzić, iż Piłsudski otrzymał wotum zaufania Sejmu ${ }^{10}$. Uchwała z 20 lutego 1919 r. była więc pierwszym aktem kontroli parlamentarnej władzy wykonawczej w II Rzeczypospolitej w pełnym tego słowa znaczeniu. Należy przy tym przyjąć, że skoro Rada Ministrów była powoływana przez Tymczasowego Naczelnika Państwa i przed nim odpowiedzialna politycznie, to również ona, jako drugi człon egzekutywy, uzyskała na mocy tego aktu ,absolutorium” ze sprawowania swych funkcji.

W małej konstytucji kontroli parlamentarnej władzy wykonawczej poświęcone zostały przepisy art. II ust. 3-5. W odniesieniu do zagadnienia tworzenia rządu postanowiono, że gabinet miał być powoływany w pełnym składzie przez Naczelnika Państwa, który powinien to czynić ,na podstawie porozumienia z Sejmem”"11. W małej konstytucji nie regulowano szczegółowo kwestii trybu powoływania rządu oraz skutku braku porozumienia naczelnika z Sejmem, co miało w przyszłości zrodzić poważny spór między nimi. Należy zaznaczyć, że 16 czerwca 1922 r. SU zainspirowany wątpliwościami Naczelnika Państwa dokonał wykładni autentycznej art. II ust. 3 małej konstytucji, noszącej wszelkie znamiona nowelizacji tymczasowej ustawy zasadniczej. W wykładni tej, uszczuplającej kompetencje Naczelnika Państwa i zwiększającej uprawnienia Sejmu, przyjęto założenie, że inicjatywa w sprawie desygnowania kandydata na premiera należy „z reguły” do Naczelnika Państwa. Jednak gdyby on z niej nie skorzystał lub Sejm za pomocą organu regulaminowo ustanowionego kandydatury tej nie zatwierdził, inicjatywa wyznaczenia kandydata na szefa gabinetu miała przechodzić na izbę zastępowaną przez tenże organ. Organem tym miała być ustanowiona w tym czasie przez Sejm Komisja Główna. We wspomnianej wykładni postanowiono ponadto, że nowo mianowany rząd miał obowiązek uzyskania od plenum Sejmu wotum zaufania, co miało być ostatnim aktem jego inwestytury ${ }^{12}$. W literaturze przedmiotu podkreślono, że zagwarantowanie sobie przez Sejm uprawnienia do uczestnictwa w powoływaniu rządu

9 Z. Witkowski, Status ustrojowy Rady Ministrów w konstytucjach polskich okresu międzywojennego, [w:] Rada Ministrów. Organizacja i funkcjonowanie, red. A. Bałaban, Kraków 2002, s. 51.

10 Ibidem, s. 64-65.

11 Z. Witkowski (ibidem, s. 53) określa ten wymóg jako ,wyraźny, chociaż nie wystarczająco precyzyjnie prawniczo sformułowany".

12 Sprawozdanie stenograficzne z 318. posiedzenia Sejmu Ustawodawczego w dniu 16 czerwca 1922 r. [dalej: spr. sten. SU], 1. 9-75; „Kurier Polski”, 17 VI 1922, nr 163. 
oznaczało usankcjonowanie w polskim prawie pozytywnym praktyki ustrojowej wytworzonej w drodze zwyczaju w parlamentaryzmie zachodnioeuropejskim ${ }^{13}$.

W świetle ugruntowanej w doktrynie wykładni małej konstytucji prawo udzielenia inwestytury rządowi przysługiwało łącznie dwu organom władzy naczelnej — aspirującemu do roli suwerena SU oraz głowie państwa. Wszystkie czynności procesu powoływania gabinetu i modelowania jego składu, takie jak: prowadzenie rozmów i konsultacji ze stronnictwami politycznymi, desygnowanie i mianowanie premiera, łączenie funkcji szefa rządu z urzędem ministra resortowego, powoływanie wicepremiera, mianowanie ministrów i podsekretarzy stanu oraz ewentualnych ministrów bez teki, łączenie stanowisk w rządzie z zasiadaniem w parlamencie, zaprzysiężenie gabinetu, a także przedstawienie się nowo powołanego rządu Sejmowi wraz z programem jego prac i wyrażenie dlań akceptacji przez parlament - poza wskazaniem na Naczelnika Państwa, jako podmiot powołujący rząd w pełnym składzie ,na podstawie porozumienia z Sejmem” — nie znajdowały umocowania w przepisach tymczasowej ustawy zasadniczej. Część z wymienionych kwestii była już jednak unormowana w pozytywnym prawie ustrojowym, a konkretnie w ciągle obowiązującym dekrecie Rady Regencyjnej z 3 stycznia 1918 r., którego odnośne przepisy omówiono wcześniej. Pozostałe kwestie odnoszące się do budowy rządu i procedury jego powoływania podlegały wykształconej w parlamentaryzmie zachodnioeuropejskim regulacji prawnozwyczajowej, recypowanej w początkach drugiej niepodległości na grunt polski, a także wypracowanej ad casum rodzimej praktyce ustrojowej.

Enigmatyczność przepisów małej konstytucji w kwestii powoływania rządu rodziła jeszcze jedną zasadniczą trudność odnoszącą się do zagadnienia zmian personalnych w gabinecie (na stanowiskach ministrów). Traktując literalnie treść odnośnej regulacji konstytucyjnej, należało przyjąć, co podkreśla powojenna literatura przedmiotu, że każdorazowa zmiana na stanowisku ministra wymagała akceptacji Sejmu ${ }^{14}$. Praktyka ustrojowa nie poszła jednak w tym kierunku i zmiany w obrębie gabinetów dokonywane były samodzielnie przez Naczelnika Państwa, działającego motu proprio w odniesieniu do resortów ,zastrzeżonych” dla jego gestii, bądź na wniosek szefa rządu w stosunku do pozostałych ministrów. Sejm był jedynie zawiadamiany pisemnie post factum o dokonanej rekonstrukcji gabinetu ${ }^{15}$.

Zarówno naczelnik, jak i rząd ponosili odpowiedzialność przed Sejmem za sprawowanie swych urzędów. Zrównanie przesłanek i zakresu odpowiedzialności głowy państwa z rządem określono w doktrynie powojennej jako kuriozalne w świetle ,teoretycznych założeń systemu parlamentarnego"16. Odpowiedzialność ta miała charakter łączny (podwójny), bowiem, jak to już zaznaczono, każdy akt państwowy Naczelnika Państwa

13 M. Pietrzak, Rzady parlamentarne w Polsce w latach 1919-1926, Warszawa 1969, s. 48-49.

14 Ibidem, s. 163-164; P. Kierończyk, Nadrzędność parlamentu - mit czy realna alternatywa ustrojowa? Analiza wybranych przykładów, Gdańsk 2009, s. 177.

15 M. Pietrzak, op. cit., s. 164; P. Kierończyk, op. cit., s. 177; Z. Witkowski, op. cit., s. 54.

16 J. Stembrowicz, Z problematyki głowy państwa w Polsce, „Kultura i Społeczeństwo” 1977, nr 2, s. 44; R. Mojak, Instytucja prezydenta w polskim prawie konstytucyjnym w latach 1918-1935, cz. 1, „Annales Universitatis Mariae Curie Skłodowska. Sectio G” 1989, t. XXXVI, nr 19, s. 236; W.J. Wołpiuk, Naczelnik Państwa 1918-1922. Przedprezydencka forma władzy państwowej, „Przegląd Sejmowy” 2005, nr 6, s. 32. 
wymagał kontrasygnaty odnośnego (właściwego) ministra. Użycie w małej konstytucji zwrotu o odpowiedzialności Naczelnika Państwa i rządu ,za sprawowanie urzędu” zostało zinterpretowane w przedwojennej doktrynie prawa państwowego jako poddanie obu tych podmiotów zarówno odpowiedzialności politycznej, jak i konstytucyjnej, indywidualnej i solidarnej ${ }^{17}$. Teza ta $\mathrm{w}$ odniesieniu do odpowiedzialności konstytucyjnej wydaje się o tyle wątpliwa, że nosiła ona zasadnicze cechy odpowiedzialności prawnokarnej, która bez dokładnego uprzedniego określenia jej przedmiotu i formuły procesowej prowadziłaby przy próbie egzekwowania do naruszenia podstawowych zasad liberalno-demokratycznego porządku prawnego ${ }^{18}$, ujętych w postać reguł: nullum crimen sine lege poenalis anteriori oraz nulla poena sine lege poenalis anteriori. Należy przyjąć, że brak w małej konstytucji przepisów odnoszących się do rodzajów odpowiedzialności egzekutywy, w konfrontacji z ogólnymi zasadami odpowiedzialności konstytucyjnej, zbliżonej zakresowo i proceduralnie do odpowiedzialności karnej, daje podstawy do zastosowania reguły interpretacyjnej: lege non distinguente nec nostrum est distinguere (czego ustawa nie rozróżnia, tego nam nie wolno rozróżniać). Nie budzi natomiast wątpliwości w świetle przepisów małej konstytucji pociąganie egzekutywy do odpowiedzialności parlamentarnej. Jej przesłanką merytoryczną była bowiem wszelka niezgodność działania poddanego jej podmiotu (rządu) z wolą większości parlamentarnej (kwalifikacja polityczna), skutkiem zaś nie jest kara, a więc dezaprobata w postaci potępienia czynu i jego sprawcy o szczególnej intensywności, dotykającego takich podstawowych wartości dla człowieka jak życie, mienie, wolność itp. ${ }^{19}$ (charakterystyczna dla odpowiedzialności karnej i częściowo również konstytucyjnej), lecz jedynie dymisja (pozbawienie sprawowanego urzędu). Sformułowania przepisów małej konstytucji nie budzą również wątpliwości co do tego, że rząd ponosił odpowiedzialność polityczną przed Sejmem zarówno kolegialną, jak i poszczególni jego członkowie indywidualną. Indywidualną odpowiedzialność ponosił również Naczelnik Państwa. Nie może również budzić wątpliwości, że odpowiedzialność gabinetu i naczelnika nosiła charakter solidarny. Ponadto usytuowanie Naczelnika Państwa i rządu w jednakowej pozycji do Sejmu oznaczało osłabienie gabinetu w stosunku do konstytuanty, gdyż nie mógł on w razie konfliktu z nią liczyć na wsparcie głowy państwa, która nie dysponowała środkami równoważącymi odpowiedzialność polityczną, np. prawem weta ustawodawczego lub możliwością rozwiązania parlamentu²0.

17 W. Komarnicki, op. cit., Warszawa 1922, s. 67. Tezę tę, ale odwołując się do okoliczności nierozróżniania przez małą konstytucję obu rodzajów odpowiedzialności i reguł logiki, podtrzymują również m.in.: M. Pietrzak, op. cit., s. 49-50; Z. Witkowski, Prezydent Rzeczypospolitej Polskiej 1921-1935, „Studia Iuridica" 1987, t. XVIII, z. 1, s. 21; idem, Status ustrojowy..., s. 55; D. Górecki, Powstawanie władz naczelnych w odradzajacej się Polsce (1914-1919), „Acta Universitatis Lodziensis. Folia Iuridica” 1983, nr 13, s. 193; R. Mojak, op. cit., s. 236; M.M. Lipska, op. cit., s. 226. Tymczasem „nierozróżnianie” to nie to samo, co brak regulacji w uchwale z 20 lutego 1919 r. odnoszącej się do kwestii różnicowania form odpowiedzialności.

${ }_{18}$ Dostrzega problem, ale go nie rozwija Z. Witkowski, Status ustrojowy..., s. 55.

19 Confer S. Lelental, Kara kryminalna, [w:] Wielka encyklopedia prawa, Białystok-Warszawa 2000, s. 320.

${ }^{20}$ M. Pietrzak, op. cit., s. 50; Z. Witkowski, Prezydent..., s. 21; J. Zaleśny, Odpowiedzialność konstytucyjna w Drugiej Rzeczypospolitej, Warszawa 2003, s. 13. 
Pierwszym aktem uchwalonym przez SU, zmierzającym do wypełnienia licznych deficytów pozytywnego prawa ustrojowego w dziedzinie kontroli rządu była nowelizacja małej konstytucji z dnia 13 lutego 1920 r. dotycząca emisji biletów Polskiej Krajowej Kasy Pożyczkowej ${ }^{21}$, w której konstytuanta zastrzegła sobie prawo dokonywania kontroli wstępnej szeregu poczynań rządu z zakresu finansów publicznych (emisja pieniądza, innych papierów dłużnych, zaciąganie pożyczek państwowych i udzielanie gwarancji Skarbu Państwa), poprzez udzielanie na nie swej zgody. Jakkolwiek omawiana nowela nie rozstrzygała formy prawnej wymaganego ,zezwolenia”, praktyka parlamentarna już od pierwszych tygodni działalności konstytuanty antycypująco wypełniła tę lukę wymogiem sięgania po formę ustawy.

Uchwała SU z 20 lutego 1919 r. nie miała formalnie rangi ustawy, ale zarówno ówczesna doktryna, jak i praktyka ustrojowa nie podważały jej rangi konstytucyjnej. Częściowo ów formalny mankament małej konstytucji usuwała ustawa przechodnia $\mathrm{z}$ dnia 18 maja $1921 \mathrm{r}^{22}$, uchwalona w związku z zamierzonym vacatio legis dla konstytucji z 17 marca $1921 \mathrm{r}$. Ustawa przechodnia ze względu na jej treść normatywną miała, niewątpliwie, charakter ustawy konstytucyjnej. Art. 1 powołanej ustawy stanowiąc, że: „Sejm Ustawodawczy sprawuje swą władzę w dotychczasowym zakresie do chwili ukonstytuowania się władzy ustawodawczej na zasadach ustawy konstytucyjnej z dnia 17 marca 1921 roku", pośrednio nadawał sankcję ustawy konstytucyjnej tym przepisom uchwały z 20 lutego 1919 r., które określały kompetencje konstytuanty. Z kolei w art. 2 ustawy już expressis verbis określono, że: „Prawa i obowiązki obecnego Naczelnika Państwa określone w uchwale Sejmu z dnia 20 lutego 1919 r. [...] trwają do chwili objęcia urzędu przez Prezydenta Rzeczypospolitej, wybranego na podstawie ustawy konstytucyjnej z dnia 17 marca 1921 roku" ${ }^{\prime 23}$.

Z funkcją kontrolną parlamentu korespondowały bezpośrednio przepisy poprzedzającego o kilka dni inaugurację SU dekretu z dnia 7 lutego 1919 r. o Najwyższej Izbie Kontroli Państwa ${ }^{24}$ [dalej: NIKP]. Dekret ów powoływał do życia samodzielny, podlegający bezpośrednio tylko Naczelnikowi Państwa, organ przeznaczony do stałej i wszechstronnej kontroli dochodów i wydatków państwowych, wykonywania budżetu państwa, prawidłowości administrowania jego majątkiem oraz gospodarki podmiotów publicznych i prywatnych korzystających z dotacji lub gwarancji Skarbu Państwa (art. 1 ust. 1, art. 11). Prezes, wiceprezes i członkowie kolegium NIKP nie mogli równocześnie zasiadać $\mathrm{w}$ ławach poselskich ani piastować innych stanowisk publicznych i prywatnych związanych z pobieraniem wynagrodzenia (art. 4-5). Kolegium

${ }^{21}$ Uchwała Sejmu z dnia 13 lutego 1920 r. uzupełniająca uchwałę Sejmu z dnia 20 lutego 1919 r. o powierzeniu Józefowi Piłsudskiemu dalszego sprawowania urzędu Naczelnika Państwa, Dz.U. nr 17 poz. 84.

22 Ustawa przechodnia z dnia 18 maja 1921 r. do ustawy konstytucyjnej z dnia 17 marca 1921 r. w sprawie tymczasowej organizacji władzy zwierzchniej Rzeczypospolitej, Dz.U. nr 44, poz. 268.

${ }^{23}$ W czasie przesilenia rządowego w czerwcu 1922 r. o włączeniu przepisów małej konstytucji do „Wielkiej Konstytucji” - na mocy ustawy przechodniej z 18 maja 1921 r. — był przekonany poseł H. Lieberman, spr. sten. SU, pos. 321. z 23 czerwca 1922 r., ł. 6.

${ }^{24}$ Dz.P.P.P. z 1919 r. nr 14, poz. 183. 
izby rozpatrywało m.in. sprawy absolutorium dla rządu, kwestie dotyczące zamknięć rachunków państwowych oraz opinie dla władz centralnych (art. 7 ust. 1 i 3), a więc jak można domniemywać — również dla Sejmu, który mógł tym samym zażądać ich przedstawienia sobie. Prezes NIKP lub delegowany przezeń jego przedstawiciel miał prawo brać udział w obradach Sejmu, komisjach i innych ciał parlamentarnych w celu referowania wniosków izby bądź udzielania informacji i wyjaśnień. Sejm mógł zażądać obecności prezesa NIKP w obradach plenum lub innego ciała parlamentarnego (art. 8). Szczegółowe przepisy dotyczące formy rocznych zamknięć rachunków państwowych oraz kwestii absolutorium dla rządu miała wydać sama NIKP w porozumieniu z zainteresowanymi ministerstwami (art. 17 ust. 2). W dekrecie nie wspomniano wprost o stawianiu przez NIKP wniosku o udzieleniu lub odmowie udzielenia absolutorium rządowi. Zgodnie z zasadą nemo iudex in causa sua kontrola wykonania budżetu izby, stanowiącego część budżetu państwa, należała do Sejmu (art. 10) ${ }^{25}$.

\section{PROCEDURY KONTROLI EGZEKUTYWY W ŚWIETLE PRZEPISÓW TYMCZASOWEGO REGULAMINU OBRAD SEJMU USTAWODAWCZEGO ORAZ PRAKTYKI PARLAMENTARNEJ}

Do sprawowania przez konstytuantę szeroko pojętej funkcji kontrolnej oraz ustanowionych w jej ramach procedur szczegółowych odnosiły się przepisy art. 14-16, 22, 35, 45, 47-49, 51-53, 53a (ostatni artykuł wprowadzony nowelą z 17 czerwca 1922 r.) oraz art. 65 (znowelizowany uchwałą z 1 marca 1921 r.) tymczasowego regulaminu obrad SU ${ }^{26}$ z 14 lutego 1919 r. Spośród wymienionych tylko art. 53a, dotyczący utworzenia Komisji Głównej posiadającej kompetencje w dziedzinie powoływania rządu, oraz art. 45 i 65 dotyczące interpelacji, bezpośrednio wiązały się ze sprawowaniem parlamentarnej kontroli egzekutywy. Pozostałe przepisy normowały kwestie wspólne dla wykonywania wszystkich funkcji konstytuanty, z postępowaniem ustawodawczym na czele.

Do czerwca 1922 r. jedyną normą prawa pozytywnego regulującą procedurę powoływania gabinetu pod rządami małej konstytucji, jeśli nie liczyć nadal obowiązujących przepisów dekretu Rady Regencyjnej z 3 stycznia 1918 r., o czym była już mowa, był art. II ust. 3 uchwały Sejmu Ustawodawczego z 20 lutego 1919 r. W czerwcu 1922 r., w czasie poważnego kryzysu konstytucyjnego, wywołanego pociągnięciem przez Naczelnika Państwa (bez udziału konstytuanty) do odpowiedzialności politycznej drugiego gabinetu Antoniego Ponikowskiego, Sejm uchwalił nowelizację regulaminu, dodając doń w rozdziale poświęconym komisjom art. 53a, wprowadzający instytucję Komisji

${ }^{25}$ Szczegółowe omówienie przepisów dekretu z 7 lutego 1919 r. o NIKP przedstawił m.in.: R. Szawłowski, Najwyższe państwowe organy kontroli II Rzeczypospolitej, Warszawa 2004, s. 55-66.

${ }^{26}$ Tymczasowy regulamin obrad Sejmu Ustawodawczego Rzeczypospolitej Polskiej, Sejm Ustawodawczy RP 1919-1922, druk nr 1; Tymczasowy regulamin obrad Sejmu Ustawodawczego Rzeczypospolitej Polskiej z uwzględnieniem zmian [...], Sejm Ustawodawczy RP, druk nr 1, Warszawa 15 września 1921 r. Pierwotny tekst regulaminu opublikował też T. Rzepecki, Sejm Rzeczypospolitej Polskiej 1919 roku, Poznań 1920, s. 40-48. Tekst regulaminu z wykazem jego nowelizacji — z błędami i pominięciami w opracowaniu T. Koperskiej opublikowano w „Przeglądzie Sejmowym” 1993, nr 1, s. 99-110. 
Głównej ${ }^{27}$. Przepis ten głosił, że Komisja Główna została wyposażona w kompetencje: „do ustalania stanowiska większości Sejmu w stosunku do spraw przez Sejm jej zleconych, a w szczególności w stosunku do zadań z przesileniem rządowym związanych" (ust. 1). Komisję, obradującą pod przewodnictwem marszałka izby (ust. 1 in fine), tworzyło od jednego do sześciu delegatów poszczególnych klubów lub grup poselskich, wyłonionych wg parytetu jeden delegat na minimum pięciu posłów (ust. 2). Głosowanie w Komisji Głównej polegało na „rzucaniu na szalę” przez każdą delegację tylu głosów, ilu posłów reprezentowała (ust. 3), przy czym dla podjęcia decyzji odpowiadającej większości Sejmu wymagane było poparcie przez ,delegacje, reprezentujące połowę plus jeden wszystkich członków Sejmu" (ust. 4). Kształt ustrojowy ustanowionej w czerwcu 1922 r. Komisji Głównej wskazuje na inspirowanie się jej twórców przepisami konstytucji Republiki Austriackiej z 1 października 1920 r. (art. 55, 70, 75), przewidującej takąż komisję, oraz § 54 konstytucji Czechosłowacji z 29 lutego 1920 r., dotyczącym Komisji Wykonawczej ${ }^{28}$.

Spośród wymienionych wcześniej szczegółowych procedur parlamentarnych dotyczących kontroli rządu bieżącej i następczej w okresie SU tylko jedna — procedura interpelacyjna — została unormowana przepisami pozytywnego prawa parlamentarnego na poziomie regulaminu izby. W myśl art. 45 ust. 1 regulaminu grupa co najmniej 15 posłów miała prawo kierować do rządu interpelacje ${ }^{29}$. Powinny być one

27 Spr. sten. SU, pos. 319. z 17 czerwca 1922 r., 1. 3-31.

${ }^{28}$ Nowe konstytucje. Przełożone pod kierunkiem Dra Juliana Makowskiego, Warszawa 1925, s. $290-292,463,468-469$.

${ }^{29}$ Ojczyzną interpelacji jest Francja, skąd przeniknęła ona do innych krajów na kontynencie europejskim. We francuskim wydaniu z punktu widzenia formalnego interpelacja ,jest to pewien szczególny rodzaj p o s tę p o w a n i a [podkreślenia w oryginale - P.A.T.] parlamentarnego (procedury parlamentarnej); tylko w niektórych krajach nazwą tą oznacza się nie określoną procedurę, lecz d o k u m e n t na piśmie, sporządzony — w zależności od kraju — przez jednego lub grupę deputowanych, odpowiadający niekiedy dalszym jeszcze - określonym zazwyczaj w regulaminie izby — wymogom; wnoszony na ręce przewodniczącego izby, ale skierowany do rządu lub do jednego z jego członków w celu wywołania określonych skutków prawno-politycznych. Wniesienie interpelacji ma z reguły na celu uzyskanie od rządu informacji i wyjaśnień w sprawie, która nie znajduje się na porządku obrad izby; otwarcie — za zgodą izby — debaty parlamentarnej nad tą sprawą, tj. stworzenie możliwości wyłożenia i wymiany poglądów jej dotyczących; wywarcie przez parlament wpływu na działalność rządu w dziedzinie obejmującej sprawę, o którą chodzi; urzeczywistnienie politycznej odpowiedzialności rządu lub określonego ministra przez udzielenie mu — w związku z przebiegiem debaty nad interpelacją — wotum zaufania lub wotum nieufności"; A. Gwiżdż, Interpelacja i procedury podobne w burżuazyjnym prawie państwowym, „Państwo i Prawo” 1963, z. 4, s. 615-616. Przedwojenna doktryna polska na podstawie obserwacji rodzimej praktyki nadawała interpelacji węższe, w odniesieniu do celów, znaczenie, twierdząc, że: „Interpelacja, jako jedna z form parlamentarnej kontroli działalności rządu, posiada charakter interwencji, skierowanej za pośrednictwem izby do rządu lub ministra w pewnej konkretnej sprawie. Przedmiot i zakres interpelacji może dotyczyć całokształtu działalności rządu, tj. wszystkich dziedzin, spraw i materii z funkcją rządzenia związanych, nie wyłączając aktów rządowych natury personalnej, jak nominacje, awanse itp. — jednak w części nie wkraczającej w swobodną decyzję władzy, wyraźnie ustawą zastrzeżoną. Przedmiotem interpelacji nie mogą być również te decyzje natury personalnej, których powzięcie pozostaje z związku z pracami komisji dyscyplinarnych i kompetencją sądów. Celem interpelacji jest przywrócenie naruszonego porządku prawnego, naprawienie wyrządzonej krzywdy lub inne zadośćuczynienie zasadom słuszności albo powszechnemu poczuciu społecznej sprawiedliwości”. A. Majkowski, Uwagi ogólne o technice prac parlamentarnych, Warszawa 1937, s. 21. 
składane do marszałka, który miał je komunikować „Prezydentowi Rady Ministrów z zapytaniem, kiedy Rząd zechce udzielić wyjaśnień". Po otrzymaniu odpowiedzi, „a w każdym razie nie później niż po upływie miesiąca”, należało rozumieć, że następowało to również w sytuacji zwłoki rządu w udzieleniu odpowiedzi na interpelację, co potwierdził w jednej ze swych wypowiedzi na plenum marszałek - miał on umieszczać interpelację na porządku dziennym plenum izby. Z brzmienia omawianego przepisu wynikało, że odnosiło się to do każdej interpelacji, ale dyskusja nad interpelacją miała być dopuszczana tylko wówczas, gdy Sejm „uzna jej potrzebę”, a więc miała być otwierana - z zasady — tylko wyjątkowo. $Z$ ust. 2 cytowanego artykułu regulaminu wynika, że gabinet miał odpowiadać na interpelacje z reguły ustnie, a fakultatywnie (wedle własnego uznania) na piśmie. Jeśli odpowiedź miała być ustna, to należało sądzić, że musiało się to odbyć z trybuny sejmowej. Cytowany przepis postanawiał też, że Sejm miał odpowiedź rządu na interpelację (każdą) przyjmować bądź nie do wiadomości. Należało więc przypuszczać, że stanowisko izby miało być przyjmowane w głosowaniu lub tacite. W literaturze przedmiotu zwrócono uwagę, że przepisy art. 45 regulaminu konstytuanty nie dawały jej marszałkowi żadnej jurysdykcji nad zgłaszanymi interpelacjami ${ }^{30}$. W dniu 1 marca $1921 \mathrm{r}$. SU uzupełnił dotychczasowy art. 65 regulaminu o drugi ustęp, w którym postanawiał, że pełne teksty m.in. interpelacji, wniesionych zgodnie z regulaminem i w całości bądź ogłoszonych w izbie z tytułu, stawały się częścią składową obrad tego posiedzenia, na którym zostały zgłoszone do laski marszałkowskiej i miały być (w postaci drukowanej) dołączane do druków (protokołów, stenogramów) sejmowych ${ }^{31}$. Uzupełnienie to istotnie modyfikowało normę zawartą $\mathrm{w}$ art. 45 regulaminu, bowiem z pierwotnego jej brzmienia wynikało, że o treści interpelacji plenum Sejmu miało się dowiadywać dopiero po udzieleniu na nią odpowiedzi przez rząd i po postawieniu jej przez marszałka na porządku dziennym obrad. Choć nie było to pewne ze względu na niejasność powołanego przepisu, od marca 1921 r. treść interpelacji, nawet gdy była zakomunikowana izbie tylko z tytułu — co było powszechną praktyką od początku funkcjonowania konstytuanty, a teraz znalazło umocowanie w przepisie regulaminu - musiała być wydrukowana i dołączona (jako załącznik) do protokołu obrad posiedzenia Sejmu. Praktyka interpelowania rządu w okresie konstytuanty od początku wyraźnie odbiegała w wielu miejscach od litery art. 45 regulaminu, o czym będzie jeszcze mowa.

Wcześniej powiedziano, że $\mathrm{w}$ ramach funkcji kontrolnej rządu konstytuanta stosowała pięć szczegółowych procedur parlamentarnych. Były nimi postępowania: w sprawach inwestytury rządu, w sprawach wotum zaufania dla gabinetu (ministra), w sprawach wotum nieufności dla rządu (ministra), w sprawach interpelacji oraz postępowanie z udziałem komisji śledczej. Niżej przedstawione zostaną syntetyczne uwagi obrazujące cechy tych procedur w kolejności, w jakiej zostały wymienione.

\footnotetext{
${ }_{30}$ A. Gwiżdż, Prawo interpelacji posła na Sejm PRL, „Państwo i Prawo” 1956, z. 11, s. 762.

${ }^{31}$ Spr. sten. SU, pos. 214. z 1 marca 1921 r., 1.16.
} 
W odniesieniu do postępowania w sprawach inwestytury rządu należy zauważyć, że z chwilą zebrania się SU oraz tymczasowego określenia podstawowych zasad ustroju politycznego RP w małej konstytucji zaistniały wszystkie niezbędne wymogi formalne do zainicjowania systemu rządów parlamentarnych, których podstawowym warunkiem było posiadanie przez rząd poparcia parlamentu (większości parlamentarnej). Ponieważ rząd Ignacego Paderewskiego kontynuował działalność potwierdzoną udzieleniem mu ponownej inwestytury, tym razem przez Naczelnika Państwa i Sejm Ustawodawczy, a nie posiadał poparcia większości izby skupionej w koalicji rządowej zawiązanej na jej forum, miał charakter gabinetu pozaparlamentarnego (uważanego w systemie parlamentarnym za rząd tymczasowy, przejściowy), który miał działać do momentu zawiązania się większościowej koalicji rządowej w Sejmie.

W okresie funkcjonowania SU działalność prowadziło osiem gabinetów rządowych (w kolejności: pozaparlamentarny Paderewskiego, koalicyjny Leopolda Skulskiego, pozaparlamentarny Władysława Grabskiego, rząd „,wielkiej koalicji” Wincentego Witosa, dwa pozaparlamentarne rządy Antoniego Ponikowskiego, pozaparlamentarny Artura Śliwińskiego oraz pozaparlamentarny Juliana Nowaka) ${ }^{32}$. Pięć rządów, począwszy od gabinetu Skulskiego, a skończywszy na drugim ministerium Ponikowskiego, zostało utworzonych przy czynnym zaangażowaniu konstytuanty działającej via Konwent Seniorów i relatywnie biernej, z wyjątkami obsady stanowisk niektórych ministrów, postawie Naczelnika Państwa. Natomiast dwa ostatnie gabinety zostały utworzone w warunkach głębokiego kryzysu konstytucyjnego wywołanego przez J. Piłsudskiego po zdymisjonowaniu na początku czerwca 1922 r. drugiego rządu Ponikowskiego.

Rząd Paderewskiego utworzony na miesiąc przed ukonstytuowaniem się SU, w dniu złożenia przez Naczelnika Państwa władzy w ręce konstytuanty i podjęcia rzeczonej uchwały o powierzeniu mu dalszego sprawowania urzędu głowy państwa, ustami I. Paderewskiego przedstawił izbie sprawozdanie z dotychczasowej działalności ${ }^{33}$ i zgłosił swoje ustąpienie. Deklaracja dymisji powinna stanowić otwarcie przesilenia rządowego i rozpoczynać rokowania w sprawie powołania nowego gabinetu. Ponieważ jednak funkcję głowy państwa sprawował nadal J. Piłsudski, który w myśl przepisu dopiero co uchwalonej małej konstytucji, jako Naczelnik Państwa powoływał „Rząd w pełnym składzie na podstawie porozumienia z Sejmem" i — sięgając do wcześniejszej praktyki ustrojowej - miał również prawo odwoływania gabinetu, premier Paderewski złożył jeszcze tego samego dnia właśnie na jego ręce pisemną prośbę o zwolnienie „wraz z całym gabinetem ministrów” z zajmowanych urzędów. Piłsudski do prośby rządu jednak się nie przychylił, odpowiadając Paderewskiemu w następujących słowach: „W porozumieniu z Sejmem Ustawodawczym w osobie Jego Marszałka, zawiadamiam Pana Prezydenta, że do zgłoszonej przez niego wraz z całym gabinetem w dniu 20 lutego 1919 r. dymisji, jako wywołanej względami natury

32 Gabinety Drugiej Rzeczypospolitej, red. J. Faryś i J. Pajewski, Szczecin-Poznań 1991, s. 41-104; Kto byt kim w Drugiej Rzeczypospolitej, red. J.M. Majchrowski i in., Warszawa 1994, s. 21-24; Exposé premierów polskich 1918-2001, oprac. B. Sygit, Toruń 2001, s. 29.

${ }^{33}$ Spr. sten. SU, pos. 3. z 20 lutego1919 r., 1. 59-74. 
formalnej, przychylić się nie mogę i powierzam Panu oraz wszystkim Jego Kolegom ministrom sprawowanie nadal dotychczasowych urzędów"34.

Ponieważ Naczelnik Państwa odmówił przyjęcia dymisji gabinetu Paderewskiego, izba podjęła debatę nad sprawozdaniem premiera oraz uzupełniającym je wystąpieniem ministra skarbu. W debacie, nie licząc głosów w sprawie sprostowań, wzięło udział 15 mówców, którzy przemawiali łącznie przez ok. osiem godzin. Wszyscy, z wyjątkiem jednego, reprezentowali kluby sejmowe, bądź, jak w przypadku posłów żydowskich, poszczególne frakcje wyodrębniające się w zrzeszającym ich klubie federacyjnym. Zgodnie z ustaleniami podjętymi przez Konwent Seniorów SU, posłowie „przemawiali po kolei według tego, jak silną przedstawiają frakcję" ${ }^{35}$. „Ponieważ w dyskusji nad exposé premiera rządu wolno poruszać wszystkie sprawy państwowe - notował bezpośredni świadek debaty - a w danym razie było to w dodatku pierwsze publiczne wystąpienie stronnictw [w Sejmie - P.A.T.], więc przedstawiciele ich starali się skorzystać ze sposobności i ustosunkować się do wszystkich spraw najważniejszych"36. Zgłoszony w czasie debaty przez prawicowy klub Związku Sejmowego Ludowo Narodowego wniosek o wotum zaufania dla rządu Paderewskiego przeszedł większością w trybie głosowania ,przez powstanie z miejsc ${ }^{\prime 37}$.

${ }^{34}$ Ibidem, pos. 4. z 22 lutego 1919 r., ł. 95. Zacytowane wyżej pismo Naczelnika Państwa wymaga kilku zdań komentarza. Otóż mamy w nim do czynienia z noszącą charakter precedensu notyfikacją odwrotności postępowania naczelnika w porównaniu z formułą przyjętą przy powoływaniu rządu. Dowiadujemy się, że J. Piłsudski porozumiał się z Sejmem „w osobie Jego Marszałka”, a więc przewodniczący izby stał się tu niejako personifikacją całej konstytuanty i zastąpił ją stanowiąco w ustaleniach z Naczelnikiem Państwa. J. Piłsudski stwierdził, że zgłoszona dymisja rządu była spowodowana „względami natury formalnej”, podczas gdy — w domyśle — złożenie przezeń urzędu w ręce SU motywowane było okolicznościami natury zasadniczej (prawnokonstytucyjnej) i stanowiło wypełnienie dyspozycji normy zawartej w art. 1 dekretu z 22 listopada $1918 \mathrm{r}$. Względy natury formalnej (proceduralnej), podyktowane normą prawa zwyczajowego zaczerpniętą z praktyki konstytucyjnej krajów zachodnich, nakazujące złożenie dymisji przez dotychczasowy rząd po zebraniu się parlamentu nowej kadencji, miały mieć — w rozumieniu Naczelnika Państwa i reprezentującego Sejm marszałka - niejako znaczenie drugorzędne w porównaniu z względami natury materialnoprawnej, zobowiązującymi naczelnika do złożenia urzędu. Wykładnia taka budzi wątpliwości o tyle, że art. 2 powołanego dekretu nie tylko zakładał wygaszenie z chwilą zebrania się SU kompetencji naczelnika do mianowania rządu, ale stanowił również o przejściu z tą chwilą uprawnienia do egzekwowania odpowiedzialności gabinetu na konstytuantę. Normy z art. 2 dekretu miały, podobnie jak norma z art. 1 , charakter materialnoprawny, a nie formalny. Należy zauważyć, że oświadczenie Piłsudskiego o odrzuceniu prośby o dymisję rządu Paderewskiego uzupełnione jest jednak konstytutywnym stwierdzeniem o powierzeniu wszystkim członkom gabinetu sprawowania „nadal dotychczasowych urzędów”. Zastosowano tu więc formułę typową dla nadawania gabinetowi inwestytury w ramach tzw. inwestytury podzielonej czy też dwustopniowej, dokonującej się z udziałem głowy państwa i parlamentu. Naczelnik Państwa, postępując tym razem w myśl przepisu małej konstytucji i działając w porozumieniu z marszałkiem Sejmu zastępującym izbę, nadał rządowi Paderewskiego nową inwestyturę, której drugi akt, w postaci wotum zaufania izby, miał się dokonać kilka dni później po debacie nad exposé premiera i ministra skarbu.

${ }^{35}$ Ibidem, pos. 4. z 22 II 1919 r., ł. 153.

${ }^{36}$ R. Wojdaliński, Relacje posta na Sejm Ustawodawczy (1919-1922), t. I, s. 102, mps w Bibliotece Zakładu Narodowego im. Ossolińskich we Wrocławiu [dalej: Ossolineum], sygn. 14108/II.

${ }^{37}$ Spr. sten. SU, pos. 4. z 22 lutego 1919 r., 1. 101-151; pos. 5. z 24 lutego 1919 r., 1. 160-193; pos. 6. z 25 lutego 1919 r., ł. 203-240; R. Wojdaliński, op. cit., s. 108. 
Upadek rządu I. Paderewskiego późną jesienią 1919 r. doprowadził do wykształcenia się charakterystycznej dla okresu konstytuanty procedury powoływania (inwestytury) rządu, w której odgrywała ona dominującą rolę. Praktyka ta aż po czerwiec 1922 r. układała się następująco. Przyjęcie dymisji gabinetu przez Naczelnika Państwa powodowało zawieszenie obrad plenarnych Sejmu, a nierzadko również komisji sejmowych. Marszałek izby zwoływał niezwłocznie posiedzenie Konwentu Seniorów, w czasie którego była rozstrzygana na początku formuła polityczna przyszłego gabinetu, a mianowicie, czy ma to być rząd parlamentarny, oparty na koalicji stronnictw sejmowych, czy też gabinet pozaparlamentarny, popierany, a raczej tolerowany, przez frakcje skupiające większość posłów konstytuanty na zasadzie ,jak się nie ma, co się lubi, to się lubi, co się ma". W okresie do czerwca 1922 r. tylko dwa gabinety, spośród sześciu utworzonych do tego momentu, miały formułę rządów parlamentarnych (gabinety Skulskiego i Witosa), przy czym żaden z nich nie był klasycznym rządem większościowym. Rząd Skulskiego był gabinetem koalicyjnym, ale mniejszościowym, uciekającym się do udziału w jego składzie ministrów niepartyjnych (rząd taki nazywano też „półparlamentarnym” lub „półfachowym”), zmuszonym do korzystania z „tolerancji” niewchodzących do jego koalicyjnego zaplecza dwóch klubów centrowych. Rząd Witosa był zaś w pierwszym okresie swego istnienia gabinetem „wielkiej koalicji”, zawiązanym w okolicznościach politycznych określanych mianem sytuacji „Ojczyzna w niebezpieczeństwie”. Formalne powołanie obydwu wymienionych rządów, a ściśle określenie ich formuły politycznej i wytypowanie kandydatur szefów gabinetów przez Konwent Seniorów, poprzedzone było konsultacjami politycznymi toczącymi się poza jego obrębem (w przypadku rządu Skulskiego między zainteresowanymi stronnictwami, w odniesieniu do gabinetu Witosa zaś na posiedzeniu Rady Obrony Państwa), sfinalizowanymi formalnym zawiązaniem koalicji sejmowych. Posiedzenie i decyzja konwentu miały w takiej sytuacji jedynie charakter deklaratoryjny.

W sytuacji gdy zawiązanie sejmowej koalicji rządowej — ze względu na różnice programowe i taktyczne dzielące stronnictwa parlamentarne - było niemożliwe, rola Konwentu Seniorów rosła. Ciało to musiało bowiem wytypować kandydata na premiera przyszłego rządu i zgrupować kluby, które gotowe byłyby zapewnić tworzonemu gabinetowi pozaparlamentarnemu poparcie bezwzględnej większości posłów. Różnice między klubami sejmowymi prowadziły nierzadko w takiej sytuacji do zwoływania kilku kolejnych posiedzeń konwentu, w czasie których następowało „ucieranie” kandydatur premiera i ważniejszych ministrów (w znaczeniu obsady kluczowych ministerstw) oraz kompletowanie poparcia klubów sejmowych. Często posiedzenia Konwentu Seniorów przedzielały rundy rokowań międzyklubowych i indywidualne konsultacje prowadzone przez marszałka Trąmpczyńskiego z przywódcami stronnictw parlamentarnych w jego sejmowym mieszkaniu. Niekiedy — jak zdarzyło się przy misjach Paderewskiego na przełomie listopada i grudnia 1919 r., przed wyłonieniem się kandydatury W. Grabskiego w czerwcu 1920 r. oraz przed wypracowaniem koalicyjnej formuły „rządu obrony narodowej” w lipcu tegoż roku — do rozmów na 
temat konkretnej formuły rządu włączał się Belweder, do którego Naczelnik Państwa zapraszał liderów frakcji parlamentarnych na indywidualne konsultacje bądź zbiorowe narady. Rzadziej natomiast J. Piłsudski zjawiał się w gmachu Sejmu dla odbycia zbiorowej narady ze stronnictwami. We wrześniu 1921 r. i marcu 1922 r., a więc przed utworzeniem obu gabinetów Ponikowskiego, Naczelnik Państwa zaniechał wpływania na stronnictwa sejmowe w sprawach poszukiwania formuły politycznej gabinetu i typowania kandydata na premiera. Zdawał się zatem zajmować jeszcze bardziej wyczekującą i spolegliwą wobec konwentu i jego decyzji postawę niż zwykł to czynić do lata $1920 \mathrm{r}$. Nie pozostawał natomiast bierny w kwestiach planowanej przez polityków desygnowanych przezeń formalnie na stanowisko premiera, obsady personalnej resortów uważanych za sferę swych wpływów w rządzie (tzw. resortów belwederskich), czyli ministerstw spraw wojskowych, zagranicznych i wewnętrznych.

Kandydat na szefa rządu przed formalną decyzją konwentu albo w trakcie jego posiedzenia (jeżeli nie brał w nim udziału, to drogą telefoniczną), a w ostateczności tuż po zakończeniu jego posiedzenia składał na ręce marszałka Sejmu deklarację podjęcia się misji utworzenia rządu. Osiągnięcie kompromisu w sprawie formuły personalno-afirmacyjnej wszystkich czterech tworzonych przed czerwcem 1922 r. rządów pozaparlamentarnych odbywało się zawsze na posiedzeniu konwentu. Przewodniczący obradom marszałek izby wymieniał nazwisko potencjalnego kandydata na szefa rządu i wzywał po kolei reprezentantów zasiadających w konwencie klubów parlamentarnych do składania deklaracji poparcia dla proponowanego szefa nowego gabinetu. Liderzy frakcji sejmowych w swych wypowiedziach za lub przeciw rzucali na szalę taką liczbę głosów, jaką reprezentował ich klub. Zdarzały się jednak przy takiej okazji, $i$ to stosunkowo często, wypowiedzi niejasne, obwarowane licznymi zastrzeżeniami i warunkami, na podstawie których trudno było jednoznacznie wywnioskować, czy dany klub jest za postawioną kandydaturą, czy też przeciw niej. Głosy poparcia były skrzętnie zliczane i obwieszczano zebranym, czy przyszły gabinet, personifikowany przez wymienionego kandydata na premiera, może liczyć na poparcie bezwzględnej większości posłów. Jeżeli tak, to rola konwentu zastępującego cały Sejm dobiegała końca, jeżeli nie, posiedzenie zamykano i rozpoczynała się nowa runda konsultacji poprzedzająca zwołanie kolejnego zebrania. Pozytywna decyzja Konwentu Seniorów typująca kandydata na premiera nabierała charakteru konstytutywnego. Było to więc faktyczne wyznaczenie szefa przyszłego rządu, czyli desygnacja w znaczeniu materialnym. Marszałek Sejmu udawał się następnie osobiście do Belwederu i komunikował ją na piśmie oraz ustnie Naczelnikowi Państwa, zawiadamiając go o wytypowanym kandydacie oraz wymieniając frakcje parlamentarne gotowe poprzeć tworzony przezeń rząd. Naczelnik, co potwierdzają fakty, akceptował bez wyjątku (lub raczej przyjmował do wiadomości, nieraz z wyraźną niechęcią) decyzję konwentu co do charakteru gabinetu (parlamentarny lub pozaparlamentarny) i osoby jego szefa. Następnie wzywał niezwłocznie do siebie kandydata na premiera, formalnie pytał go o zgodę na podjęcie się misji utworzenia gabinetu i wręczał mu dekret desygnacyjny z użyciem w jego osnowie formuły: „w porozumieniu z Sejmem Ustawodawczym w osobie 
Jego Marszałka"38. Dokonywał zatem desygnacji premiera tylko w znaczeniu formalnym, bo materialna, jak już wspomniano, należała do konwentu.

Akty desygnacji premiera i rządu (materialny i formalny) dokonywane od jesieni 1919 r. nie kończyły w systemie ustrojowym małej konstytucji procesu inwestytury rządu, ale stanowiły tylko jego pierwszy etap. Drugim było uzyskanie wotum zaufania Sejmu, które w okresie poprzedzającym wspomnianą wykładnię autentyczną tymczasowej ustawy zasadniczej z czerwca 1922 r. stało się wymogiem prawno-zwyczajowym recypowanym z parlamentaryzmu zachodnioeuropejskiego.

W sytuacji przejęcia inicjatywy w dziedzinie wyłaniania rządu przez konstytuantę, począwszy od późnej jesieni 1919 r. (od chwili utworzenia gabinetu L. Skulskiego ${ }^{39}$ ), procedura udzielenia inwestytury parlamentarnej rządowi przebiegała różnie od postępowania w sprawie debaty nad exposé rządu Paderewskiego z końca lutego 1919 r. Etap formalnego udzielenia inwestytury parlamentarnej nowemu rządowi obejmował od końca 1919 r. następujący ciąg czynności na plenum Sejmu: exposé premiera uzupełnione odrębnym wystąpieniem programowym ministra skarbu; przyjęcie wniosku o otwarcie debaty nad deklaracją programową rządu i jej odłożenie do następnego posiedzenia w celu odbycia narad w klubach poselskich; debata nad exposé polegająca na wystąpieniach mówców wytypowanych przez kluby w kolejności odzwierciedlającej wielkość frakcji — od największej do najmniejszej (rzutowało to również wprost proporcjonalnie na długość przemówienia, ale z wyjątkiem debaty po powołaniu pierwszego rządu Ponikowskiego ${ }^{40}$ ); głosowanie nad postawionym w dyskusji wnioskiem o ,przyjęcie do wiadomości" deklaracji programowej rządu, a więc o udzielenie mu wotum zaufania (tak w przypadku rządu Nowaka, kiedy to udzielenie wotum zaufania - wymagane na skutek uchwały Sejmu z 16 czerwca 1922 r. dotyczącej wykładni autentycznej małej konstytucji — odbyło się jako głosowanie ,przez drzwi”"41), względnie o odmowę

${ }^{38}$ Confer spr. sten. SU, pos. 318. z 16 czerwca 1922 r., ł. 11-12, 17-18, 21, 40-43; M. Rataj, Pamiętniki, Warszawa 1965, s. 62-63; S. Krukowski, Sejm Ustawodawczy 1919-1922. Uwagi o składzie i dziatalności, „Czasopismo Prawno-Historyczne” 1986, z. 1, s. 106-107; Z. Kaczmarek, Wojciech Trampczyński, Poznań 1993, s. 140-145; G. Koksanowicz, Prawnoustrojowa pozycja marszałka Sejmu w okresie II Rzeczypospolitej, „Przegląd Sejmowy” 2003, nr 2, s. 68-69. Zatem nie znajduje potwierdzenia w faktach zdanie A. Próchnika (Pierwsze piętnastolecie Polski niepodległej. Zarys dziejów politycznych, Warszawa 1983, s. 103), jakoby w okresie od jesieni 1919 r. do czerwca 1922 r. początkowo wolę Sejmu wyrażał jego marszałek, a następnie Konwent Seniorów, gdyż od początku podmiotem decydującym był konwent, a marszałek przedstawiał Naczelnikowi Państwa jedynie jego decyzję.

39 Powołanie gabinetu Skulskiego poprzedziło podpisanie przez zjednoczony klub Polskiego Stronnictwa Ludowego oraz frakcje Narodowego Zjednoczenia Ludowego i Narodowego Związku Robotniczego „Umowy większości sejmowej”, konstytuującej przyszłą koalicję rządową. Koalicja ta miała charakter mniejszościowy, ale ,życzliwą neutralność” w stosunku do niej zadeklarowały jeszcze dwie niewielkie frakcje centrowe Narodowo Chrześcijański Klub Robotniczy i Zjednoczenie Mieszczańskie, co zapowiadało głosowanie przez nie, wespół z koalicjantami, za wnioskiem o wotum zaufania dla nowego gabinetu; vide m.in.: K. Badziak, W oczekiwaniu na przełom. Na drodze od odrodzenia do załamania państwa polskiego listopad 1918-czerwiec 1920, Łódź 2004, s. 97-121.

40 „Kurier Polski”, 1 X 1921, nr 266.

${ }^{41}$ Spr. sten. SU, pos. 333. z 3 sierpnia 1922 r., 1. 7-39; „Kurier Polski”, 4 VIII 1922, nr 211; J. Nowak, Wspomnienia z ławy rządowej, Kraków 1938, s. 45. 
wotum zaufania (tak w przypadku gabinetu Śliwińskiego, co spotkało się z poparciem większości, udzielonym — precedensowo — w głosowaniu imiennym ${ }^{42}$ ).

Przedstawiony schemat postępowania nie był jednak kanonem sztywnym, miał liczne odstępstwa generowane okolicznościami bieżącej sytuacji politycznej. Listę tych odstępstw otwierał często stawiany i skwapliwie uchwalany przez większość regulaminowy wniosek formalny o zamknięcie rozprawy po wystąpieniach mówców z ważniejszych klubów poselskich, a przed mowami zapisanych do głosu reprezentantów małych frakcji, najczęściej radykalnie lewicowych, które w takiej sytuacji głośno wyrażały swoje niezadowolenie (tak w przypadkach gabinetów: Skulskiego, Grabskiego, pierwszego rządu Ponikowskiego, Śliwińskiego ${ }^{43}$ ). Drugim często stosowanym wyjątkiem od podanego schematu było udzielanie wotum zaufania nowemu rządowi w sposób dorozumiany, tacite, bez postawienia i głosowania wniosku w tej sprawie (tak w przypadkach gabinetów: Skulskiego i obu rządów Ponikowskiego ${ }^{44}$ ). Następnym odejściem od podanej formuły udzielania inwestytury parlamentarnej nowemu ministerium było łączenie exposé szefa gabinetu i towarzyszącej mu debaty parlamentarnej z rozprawą nad ważnym, okolicznościowo fundamentalnym i pilnym, projektem ustawy wniesionym przez rząd. Uchwalenie ustawy było równoznaczne z udzieleniem wotum zaufania nowemu gabinetowi inicjującemu swój polityczny żywot od przedłożonego projektu ustawy. W czasie debaty nad takim projektem ustawy odstępowano od formuły przemawiania posłów według siły reprezentowanej frakcji i zastępowano ją kolejnością wynikającą z układu listy mówców zapisanych do głosu (tak w przypadkach gabinetów Grabskiego, kiedy to procedowano projekt ustawy o Radzie Obrony Państwa ${ }^{45}$ oraz drugiego rządu Ponikowskiego, kiedy przeprowadzano I czytanie projektu budżetu państwa ${ }^{46}$ ). Sygnalizowana zmiana kolejności wystąpień poselskich była praktykowana również w debatach nad deklaracjami programowymi rządów Śliwińskiego i Nowaka ${ }^{47}$. Wspomniane łączenie debaty nie ograniczało się tylko do rządowych projektów ustaw, ale odnosiło się również do ważnych ze względu na okoliczności polityczne sprawozdań komisji sejmowych dotyczących wniosków poselskich (tak w przypadku gabinetu Witosa ${ }^{48}$ ). Innym odstępstwem od proceduralnego kanonu udzielania inwestytury parlamentarnej nowemu

42 Spr. sten. SU, pos. 324. z 5 lipca 1922 r., 1. 10-55; pos. 325. z 6 lipca 1922 r., ł. 24-49; pos. 326. z 7 lipca 1922 r., 1. 3-57; „Kurier Polski”, 29 VI 1922, nr 175; 6 VII 1922, nr 182; 7 VII 1922, nr 183; R. Wojdaliński, op. cit., t. IV, s. 119-121.

${ }^{43}$ Spr. sten. SU, pos. 106. z 19 grudnia 1919 r., ł. 23-24; pos. 156. z 30 czerwca 1920 r., 1. 8-39; pos. 157 z 1 lipca 1920 r., ł. 22-38; pos. 247. z 27 września 1921 r., ł. 6-22; pos. 248. z 30 września 1921 r., ł. 15-62; pos. 249. z 1 października 1921 r., ł. 2-48; pos. 324. z 5 lipca 1922 r., 1. 10-18; pos. 325. z 6 lipca 1922 r., 1. 24-47; „Kurier Polski”, 29 VI 1922, nr 175; 6 VII 1922, nr 182.

${ }^{44}$ Spr. sten. SU, pos. 106. z 19 grudnia 1919 r., 1. 23-24; pos. 249. z 1 października 1919 r., 1. 48; pos. 303. z 5 maja 1922, ł. 102.

45 Ibidem, pos. 156. z 30 czerwca 1920 r., 1. 8-39; pos. 157. z 1 lipca 1920 r., 1. 22-38.

46 Ibidem, pos. 296. z 4 kwietnia 1922 r., 1. 104; pos. 301. z 28 kwietnia 1922, 1. 14-34; pos. 302. z 4 maja 1922 r., ł. 12-85; pos. 303. z 5 maja 1922 r., ł. 4-102.

${ }^{47}$ Ibidem, pos. 324. z 5 lipca 1922 r., 1. 10-55; pos. 325. z 6 lipca 1922 r., 1. 24-47; pos. 326. z 7 lipca 1922 r., 1. 3-57; pos. 333. z 3 sierpnia 1922 r., ł. 7-39.

48 Ibidem, pos. 166. z 24 lipca 1920 r., 1. 7-23. 
rządowi było odwlekanie w czasie otwarcia plenarnej rozprawy nad exposé szefa gabinetu (tak w przypadku drugiego rządu Ponikowskiego), ale zdarzało się również postępowanie zupełnie odmienne - niezwłocznie przystępowanie do rozprawy bez zwyczajowej przerwy na narady w klubach (tak w przypadkach gabinetów Śliwińskiego i Nowaka). Osobliwością była również schematyzacja debaty nad exposé, sprowadzająca się do krótkich, odczytywanych z trybuny sejmowej deklaracji klubowych (tak w przypadkach rządów Witosa i Nowaka).

Dymisja drugiego rządu A. Ponikowskiego otwarła najdłuższe w dziejach II RP przesilenie rządowe trwające dwa miesiące, w czasie którego Sejm dokonał wykładni autentycznej przepisu małej konstytucji w sprawie powoływania rządu i powołał do życia, w miejsce tracącego swoją rolę (ale tylko w tym procesie) Konwentu Seniorów, Komisję Główną. W trakcie tego przesilenia prawica sejmowa usiłowała usunąć z urzędu Naczelnika Państwa J. Piłsudskiego. W trakcie przesilenia naczelnik powołał 28 czerwca 1922 r. gabinet Artura Śliwińskiego. Rząd ten został de facto narzucony przez Naczelnika Państwa luźnej większości centroprawicowej SU, zastępującego się Komisją Główną, która skapitulowała na rzecz Piłsudskiego i poparła większością głosów powołanie tego gabinetu (podobnie stało się z rządem Nowaka). Nic więc dziwnego, że stronnictwa ją tworzące, a zwłaszcza ugrupowania endeckie, odebrały go jako poważne upokorzenie doznane od Piłsudskiego, którego pozycję ustrojową konstytuanta usiłowała osłabić poprzez wspomnianą wykładnię tymczasowej ustawy zasadniczej z 20 lutego 1919 r. Cenę za to, jedyną taką w całym okresie funkcjonowania SU, zapłacił gabinet Śliwińskiego, któremu izba odmówiła wotum zaufania.

Instytucja wotum zaufania dla rządu w okresie konstytuanty była nie tylko środkiem $\mathrm{w}$ procedurze inwestytury gabinetu, ale również samodzielnym narzędziem w wykonywaniu parlamentarnej kontroli egzekutywy ${ }^{49}$. Na przestrzeni całego okresu funkcjonowania SU do jej zastosowania doszło tylko raz, na początku 1921 r., w czasie funkcjonowania gabinetu W. Witosa. Rząd ten rozpoczął działalność w lipcu 1920 r. jako „,ząd wielkiej koalicji”, ale od końca listopada tegoż roku jego zaplecze parlamentarne zaczęło się stopniowo kruszyć poprzez wyłamywanie się kolejnych klubów, najpierw prawicowych (ZLN i chadecji), następnie PPS, a potem kolejnych. Zaniepokojony premier Witos zwołał 17 stycznia $1921 \mathrm{r}$. naradę stronnictw uczestniczących jeszcze w pracach gabinetu, z pytaniem o istnienie zaplecza koalicyjnego dla rządu. Obecni na naradzie przedstawiciele części klubów sejmowych uzależnili swe poparcie dla gabinetu od wystąpienia premiera z exposé na forum Sejmu ${ }^{50}$. Witos zdecydował się w tej sytuacji zabiegać o wotum zaufania konstytuanty. Exposé (zawierało w swej treści zarówno elementy sprawozdania, jak i mowy programowej) wygłosił 27 stycznia $1921 \mathrm{r}$. na plenum izby przed zaplanowanym porządkiem dziennym obrad (w myśl przepisu

${ }^{49} \mathrm{~W}$ ujęciu doktryny współczesnej wotum zaufania to ,uchwała parlamentu wyrażająca zaufanie dla rządu lub poszczególnych ministrów bądź też akceptację programu działania rządu oraz prowadzonej przez niego polityki”; S. Bożyk, Wotum zaufania, [w:] Wielka encyklopedia..., s. 1157.

${ }^{50}$ Vide A. Wątor, Gabinet Wincentego Witosa 24 VII 1920-13 IX 1921, [w:] Gabinety..., s. 72-73; spr. sten. SU, pos. 203. z 27 stycznia 1921 r., ł. 25. 
art. 22 regulaminu przedstawiciel rządu miał prawo przemawiania poza kolejnością i bez ograniczeń czasowych). Izba jeszcze tego samego dnia, na wniosek przedstawiciela Związku Parlamentarnego Polskich Socjalistów, rozpoczęła debatę nad wystąpieniem szefa rządu, która rozciągnęła się na istotne części następnych sześciu posiedzeń plenarnych (z przerwą na posiedzenia od 205. do 207.) zwołanych w okresie od 28 stycznia do 22 lutego $1921 \mathrm{r}$. W długiej debacie (nie licząc wystąpień dla sprostowań) zabrało głos 19 posłów reprezentujących większość klubów sejmowych, ale w kolejności według zapisów, a nie wielkości frakcji parlamentarnych. Jako ostatni w celach polemicznych głos zabrał ponownie premier Witos. W przedostatnim dniu debaty prezes Klubu Pracy Konstytucyjnej, poseł Jan Kanty Federowicz, zgłosił dwuczęściową rezolucję (wniosek) o wotum zaufania dla gabinetu. Obydwie części wniosku uzyskały w odrębnych głosowaniach poparcie większości posłów w trybie ,przez powstanie z miejsc” ${ }^{51}$. Tym samym rząd Witosa uzyskał zaufanie Sejmu już tylko jako gabinet większościowy.

W okresie funkcjonowania SU uruchomiono co najmniej czterokrotnie procedurę egzekwowania odpowiedzialności politycznej egzekutywy z wykorzystaniem instytucji wotum nieufnościs ${ }^{52}$. Co charakterystyczne, rozpatrywanie stosownego wniosku w osobnym punkcie porządku obrad (w odrębnym postępowaniu) zdarzyło się tylko jeden raz w odniesieniu do Naczelnika Państwa, natomiast w przypadkach dwóch szczegółowo odnotowanych w stenogramach SU postępowań tego rodzaju doszło do nich nie w osobnych punktach porządku obrad, lecz wpadkowo w ramach innych postępowań. Czwarty wspomniany przypadek jest odnotowany w stenogramie tylko wzmiankowo, bowiem podana jest tylko informacja o wniosku o wotum nieufności wobec niewskazanego konkretnie ministra sprawiedliwości, co miało się zdarzyć przed kwietniem 1922 r..$^{53}$

51 Spr. sten. SU, pos. 203. z 27 stycznia 1921 r., ł. 5-56; pos. 204. z 28 stycznia 1921 r., 1. 19-58; pos. 208. z 10 lutego 1921 r., ł. 7-67; pos. 209. z 11 lutego 1921 r., ł. 44-63; pos. 210 . z 15 lutego 1921 r., ł. 55-67; pos. 211. z 18 lutego 1921 r., 1. 20-59; pos. 212. z 22 lutego 1921 r., 1. 9-55.

${ }^{5}$ Przez pojęcie wotum nieufności rozumie się we współczesnej polskiej doktrynie uchwałę parlamentu podjętą na wniosek uprawnionej liczby deputowanych, wyrażającą brak zaufania lub dezaprobatę dla działalności rządu bądź ministra, powodującą zwykle ich dymisję. Wniosek w sprawie uchwalenia wotum nieufności może wynikać z negatywnej oceny działalności gabinetu lub ministra bądź ze zmieniających się układów partyjno-koalicyjnych; vide B. Banaszak, Wotum nieufności, [w:] Encyklopedia prawa, red. U. Kalina-Prasznic, Warszawa 1999, s. 860; A. Preisner, Wotum nieufności, [w:] Słownik wiedzy o Sejmie, red. A. Preisner, Warszawa 1995, s. 149; W. Sokolewicz, Odpowiedzialność parlamentarna Rządu RP (votum zaufania, votum nieufności, absolutorium), Warszawa 1993, s. 31-33.

53 Spr. sten. SU, pos. 296. z 4 kwietnia 1922 r., 1. 100. Jeśli taki wniosek rzeczywiście postawiono, to wiele wskazuje na to, że został on przez Sejm odrzucony, gdyż żaden z ministrów sprawiedliwości nie złożył do tego okresu dymisji w związku z uchwaleniem mu wotum nieufności. Warto też nadmienić, że instytucji wotum nieufności wobec ministra użyto skutecznie poza plenum Sejmu. Uczyniła to Komisja Spraw Zagranicznych izby (jednomyślnie, ale bez wcześniejszego formalnego postawienia wniosku w tej sprawie) na swym posiedzeniu 12 maja 1921 r. wobec (nieobecnego na jej posiedzeniu) szefa resortu spraw zagranicznych w rządze Witosa, Eustachego Sapiehy. Na skutek tej uchwały, bez zaangażowania plenum Sejmu w obalenie ministra, Sapieha podał się 24 maja 1921 r. do dymisji, która została przyjęta przez Naczelnika Państwa; vide P.A. Tusiński, Komisja Spraw Zagranicznych Sejmu Ustawodawczego (1919-1922) jako podmiot polityki zagranicznej w pierwszych latach II Rzeczypospolitej, „Wschodni Rocznik Humanistyczny” 2015, t. XII, s. 144-145. 
Pierwszy raz w konstytuancie wniosek o wotum nieufności postawiono 13 lutego 1920 r. w stosunku do gabinetu L. Skulskiego w wystąpieniu sprawozdawcy mniejszości Komisji Skarbowo-Budżetowej, socjalistycznego posła Hermana Diamanda, który zarzucił rządowi nakręcanie spirali inflacji. Wniosek sformułowano przy okazji debaty nad rządowym projektem „ustawy w przedmiocie dalszej emisji biletów Polskiej Krajowej Kasy Pożyczkowej”. Co ciekawe, funkcjonujący od kilku tygodni gabinet Skulskiego miałby ponieść odpowiedzialność polityczną za poczynania poprzedzającego go rządu Paderewskiego, a ściśle zasiadającego w jego składzie w fotelu ministra skarbu, Leona Bilińskiego. Odpowiadając, sprawozdawca większości komisji zarzucał autorom wniosku o wotum nieufności stricte polityczne, a nie merytoryczne motywy działania, wynikające z zajmowania opozycyjnego stanowiska względem rządu. W konsekwencji Sejm w głosowaniu ,przez powstanie z miejsc” odrzucił większością głosów wniosek o wotum nieufności, a następnie uchwalił w II i III czytaniu rządowy projekt ustawy zatwierdzającej dodatkową emisję pieniądza oraz rezolucję większości komisji nowelizującą małą konstytucję ${ }^{54}$, o której wzmiankowano już wcześniej. Drugi wniosek o wotum nieufności postawił na początku kwietnia 1922 r. poseł Juliusz Poniatowski z PSL „Wyzwolenie” wobec prezesa Głównego Urzędu Ziemskiego (urząd miał charakter centralnego organu administracji rządowej, podlegającego ministrowi rolnictwa) Władysława Kiernika, którego obciążono główną odpowiedzialnością za aferę sprzedaży Polsko-Amerykańskiemu Bankowi Ludowemu majątku Dojlidy w Białostockiem. Wniosek, postawiony w ramach postępowania interpelacyjnego zainicjowanego przez posłów ZLN, izba uchwaliła w trybie głosowania przez powstanie z miejsc, ale w brzmieniu zgłoszonym przez posła Witolda Teofila Staniszkisa, że: „Sejm nie przyjmuje do wiadomości odpowiedzi [na interpelację — P.A.T.] p. Prezesa Głównego Urzędu Ziemskiego" 55 . W następstwie uchwały Kiernik podał się do dymisji.

Trzeci odnotowany szerzej w źródłach przypadek sięgnięcia przez konstytuantę po procedurę egzekwowania odpowiedzialności egzekutywy zdarzył się latem 1922 r., w trakcie wspomnianego wcześniej długotrwałego przesilenia rządowego po upadku II gabinetu Ponikowskiego. Tym razem jej oścień skierowano z inicjatywy obu klubów Narodowej Demokracji przeciwko osobie Naczelnika Państwa, w odwecie za odmowę powołania gabinetu pod prezesurą Wojciecha Korfantego. Wniosek nagły odmawiający zaufania naczelnikowi wpłynął do laski marszałkowskiej 25 lipca 1922 r., a większość izby zdecydowała się go rozpatrywać w trybie pilnym na specjalnie zwołanym w tym celu posiedzeniu plenarnym Sejmu w dniu następnym ${ }^{56}$. Sytuacja wywołana wnioskiem była o tyle niebezpieczna, że ewentualna dymisja J. Piłsudskiego ze stanowiska głowy państwa, połączona $\mathrm{z}$ brakiem rządu (formalnie funkcjonował w ramach prowizorium rządowego gabinet Śliwińskiego, ale przecież i jemu odmówiono wcześniej zaufania Sejmu) pozostawiłaby państwo bez legitymizowanej konstytucyjnie całej egzekutywy.

${ }_{54}^{54}$ Spr. sten. SU, pos. 119. z 13 lutego 1920 r., 1. 23-60.

${ }_{55}$ Ibidem, pos. 296. z 4 kwietnia 1922 r., 1. 87-101.

${ }_{56}$ J. Faryś, Konflikt Naczelnika Państwa z Sejmem Ustawodawczym w 1922 roku, „Dzieje Najnowsze” 1975, nr 3, s. 50; spr. sten. SU, pos. 329. z 25 lipca 1922 r., ł. 59. 
W głosowaniu imiennym wniosek o wotum nieufności został jednak odrzucony większością 206 głosów przeciw 186, przy czterech wstrzymujących się ${ }^{57}$.

Zgłaszanie interpelacji parlamentarnych było podstawową formą — w przeważającej mierze indywidualnej - aktywności posłów SU w dziedzinie sprawowania kontroli nad rządem. Formalnie interpelacja musiała być zgłoszona przez co najmniej 15 posłów (art. 65 regulaminu), ale uzyskanie podpisu kolegów pod interpelacją, nawet z innego klubu parlamentarnego, nie sprawiało żadnej trudności, skoro w okresie konstytuanty wpłynęło ich do laski marszałkowskiej aż $3697^{58}$. Wcześniej już powiedziano, że w myśl powołanego przepisu regulaminu — wszczynanie debaty nad interpelacją miało następować co do zasady wyjątkowo, gdy Sejm „uzna jej potrzebę”. Tak też było w praktyce. $Z$ jej obserwacji wynika, że konstytuanta stosowała w istocie dwie procedury postępowania w sprawach interpelacji - uproszczoną i rozwiniętą.

Postępowanie uproszczone wykorzystywane w odniesieniu do przygniatającej liczby zgłoszonych interpelacji polegało na złożeniu jej tekstu na piśmie marszałkowi, a następnie - na najbliższym po tym fakcie posiedzeniu plenarnym izby — na odczytaniu przez urzędującego sekretarza obrad nazwiska pierwszego interpelanta pod nią podpisanego (wyjątkowo czytano kilka pierwszych nazwisk) i skwitowaniu dalszych podpisanych zwrotem „i tow.[arzyszy]”, wskazaniu adresata interpelacji oraz na określeniu kwestii, której dotyczyła, a także — na końcu prezentacji nagłówków wszystkich zgłoszonych interpelacji - wygłoszeniu przez marszałka formuły, że interpelacje prześle prezydentowi Rady Ministrów „na drodze regulaminem przepisanej”59. Wnioskowanie na podstawie danych źródłowych dotyczących biegu rozwiniętej procedury interpelacyjnej pozwala sądzić, że odpowiedzi rządu na interpelacje (na ogół udzielane na piśmie bezpośrednio przez zaczepionych ministrów, jednak relatywnie często bez dotrzymania miesięcznego terminu ${ }^{60}$ ), kierowane na ręce marszałka, były następnie doręczane przezeń interpelantom bez zawiadamiania o tym fakcie plenum Sejmu. Praktyka nieabsorbowania uwagi całej izby w tym względzie została najprawdopodobniej wymuszona ogromną liczbą zgłaszanych interpelacji. Dostarczenie odpowiedzi interpelantowi/om kończyło bieg uproszczonej procedury interpelacyjnej.

Rozwinięta procedura interpelacyjna w SU, stosowana — z założenia — wyjątkowo, biegła do momentu wpłynięcia pisemnej odpowiedzi rządu na interpelację na ręce marszałka izby bądź zawiadomienia go o zamiarze (dacie) udzielenia odpowiedzi ustnej, identycznie jak procedura uproszczona. Różnica pojawiała się od chwili wyrażenia

57 Spr. sten. SU, pos. 330. z 26 lipca 1922 r., 1. 9-22.

58 Katalogi i bazy, Parlamentaria polskie 1919-1997, Sejm 1919-1939, Sejm Ustawodawczy 1919-1922, Interpelacje; <bs.sejm.gov.pl>.

59 Dla przykładu spr. sten. SU, pos. 21. z 29 marca 1919 r., ł. 1-3; pos. 37. z 13 maja 1919 r., 1. 1-3.

${ }^{60} \mathrm{~W}$ przypadku opóźnienia odpowiedzi główny interpelant składał oświadczenie przed porządkiem dziennym o zwłoce, a marszałek zobowiązywał się do niezwłocznego zapytania ministra o przyczynę opóźnienia; np. ibidem, pos. 147. z 14 maja 1920 r., ł. 4; pos. 282. z 31 stycznia 1922 r., 1. 4-5. W ostatnim przypadku marszałek oświadczył, że na życzenie posłów zawsze interweniował w rządzie w sprawach zwłoki udzielania odpowiedzi na interpelacje, grożąc, że zgodnie z regulaminem postawi sprawę takiej interpelacji na porządku dziennym plenum izby. 
przez przedstawiciela gabinetu woli wystąpienia na plenum izby z ustną odpowiedzią na interpelację. Wówczas to norma regulaminowa wymagała od marszałka umieszczenia sprawy interpelacji na porządku dziennym plenarnego posiedzenia Sejmu. Praktyka dostarcza jednak co najmniej kilku przykładów postawienia sprawy interpelacji na porządku dziennym obrad izby nawet w przypadkach udzielenia pisemnej odpowiedzi rządu. $\mathrm{Z}$ brzmienia powołanego przepisu regulaminu nie wynika, kto rozstrzygał w sensie inicjatywnym o umieszczeniu takiej odpowiedzi na plenum - marszałek motu proprio, rząd czy też interpelanci. Pewne wzmianki źródłowe na ten temat pozwalają jednak sądzić, że najczęściej działo się to z inicjatywy gabinetu. Umieszczenie sprawy interpelacji na porządku dziennym, sygnowanej formalnie najczęściej jako odpowiedź na nią zaczepionego ministra, uruchamiało dalsze czynności postępowania interpelacyjnego teraz już z udziałem całej izby. Układ tych czynności został zasadniczo ustalony przy okazji pierwszego przypadku postawienia sprawy interpelacji na porządku dziennym obrad SU, co zdarzyło się w końcu marca 1919 r., na 21. i 22. posiedzeniu. Procedurę rozpoczynało wystąpienie zaczepionego ministra, następnie głównego interpelanta, który zgłaszał na końcu rezolucję (lub rezolucje) żądające od rządu wykonania wskazanych działań, po nim zaś zabierali głos posłowie zapisani na listę mówców. Debatę kończyło uchwalenie rezolucji interpelanta lub wniosku o przyjęcie/nieprzyjęcie odpowiedzi rządu, względnie — jak w wywołanym przypadku — odesłanie rezolucji do komisji, bowiem marszałek był zdania, że: „Podług regulaminu właściwie wolno po interpelacjach głosować tylko nad tem, czy Sejm przyjmuje odpowiedź do wiadomości, czy nie" ${ }^{61}$.

Opisana rozwinięta procedura interpelacyjna nie zawsze miała dokładnie taki przebieg w odniesieniu do innych przypadków interpelacji rozpatrywanych na plenum SU. Niekiedy izba rozpoczynała postępowanie od razu od umieszczonej w porządku dziennym obrad (albo przed porządkiem dziennym) odpowiedzi ustnej interpelowanego ministra bądź premiera bez odczytywania treści interpelacji. Następnie bez otwierania debaty odpowiedź tę przyjmowano tacite do wiadomości ${ }^{2}$ bądź czynność ta następowała po debacie $^{63}$. Innym wariantem rozwiniętej procedury interpelacyjnej było włączanie interpelacji do plenarnego biegu czynności w postępowaniach dotyczących spraw wniosków poselskich zgłaszanych pod adresem rządu, jeśli łączyła je wspólna tematyka ${ }^{64}$. Zdarzało

${ }^{61}$ Ibidem, pos. 21. z 29 marca 1919 r., 1. 33-71; pos. 22. z 31 marca 1919 r., 1. 17-50. Omawiany przypadek odesłania odpowiedzi rządu na interpelację do komisji nie był odosobniony, o czym świadczy sprawozdanie Komisji Zdrowia i Opieki Społecznej o jednej z interpelacji na posiedzeniu izby w końcu lutego 1922 r.; ibidem, pos. 289. z 25 lutego 1922 r., ł. 4-8.

${ }^{62}$ Spr. sten. SU, pos. 149. z 19 maja 1920 r., ł. 3-9; pos. 172 . z 14 października 1920 r., 1. 4-5; pos. 298. z 7 kwietnia 1922 r., 1. 35-79.

${ }^{63}$ Spr. sten. SU, pos. 145. z 7 maja 1920 r., 1. 58-63. Nieprzyjęcie przez izbę odpowiedzi rządu i prezesa NIKP na interpelację zaistniało na początku kwietnia 1922 r. we wspomnianym wcześniej postępowaniu dotyczącym afery dojlidzkiej. Odrzucenie odpowiedzi rządu nie oznaczało jednak wotum nieufności wobec gabinetu A. Ponikowskiego, lecz tylko wobec prezesa Głównego Urzędu Ziemskiego, Kiernika, obciążonego odpowiedzialnością za wprowadzenie premiera w błąd; spr. sten. SU, pos. 296. z 4 kwietnia 1922 r., 1. 53-101.

${ }^{64}$ Ibidem, pos. 25. z 4 kwietnia 1919 r., 1. 29-88; pos. 37. z 13 maja 1919 r., ł. 69-88. 
się również Sejmowi rozpatrywanie w ramach procedury rozwiniętej interpelacji kwalifikowanych jako nagłe ${ }^{65}$.

Doktryna wiąże postępowanie kontrolne z udziałem nadzwyczajnej komisji śledczej z tzw. prawem ankiety parlamentarnej. Istotą takiej komisji było wyposażenie jej w odpowiednie instrumenty oddziaływania politycznego i prawnokarnego, przy czym te ostatnie są właściwe dla katalogu uprawnień prokuratora i sądu (np. prawo wzywania świadków z obowiązkiem ich stawiennictwa, zaznaczenie obowiązku składania prawdziwych zeznań). Cel powoływania komisji śledczych przez parlament ma wyraźnie polityczny charakter (często odbywa się to pod naciskiem opinii publicznej). Uprawnienia kontrolne $w$ ramach ankiety parlamentarnej wykraczają poza rutynowy obszar działalności parlamentu i obejmują np. kontrolę organów administracji specjalnej i terenowej oraz przesłuchania osób fizycznych niezatrudnionych w aparacie rządowym. Zatem parlamentarne postępowanie śledcze stanowi swoistą konkurencję dla procesu karnego, chociaż może ono również zbierać materiał dowodowy na jego użytek. Polityczne piętno ankiety parlamentarnej powoduje, że sprawozdanie komisji śledczej ma z reguły opisową formę (nienormatywną, nieodpowiadającą formule aktu oskarżenia). Podkreśla ono nieprawidłowości działań administracji i może prowadzić do zastosowania środków odpowiedzialności członków gabinetu zarówno politycznej, jak i konstytucyjnej ${ }^{66}$.

Regulamin SU nie zawierał szczególnego umocowania prawnego dla nadzwyczajnych komisji śledczych. Podstawy normatywne ich działalności określały przepisy ogólne dotyczące komisji sejmowych oraz normy zwyczajowe. W okresie funkcjonowania konstytuanty złożono kilkanaście wniosków o powołanie nadzwyczajnej komisji śledczej ${ }^{67}$, przy czym w większości były to wnioski poselskie, ale zdarzały się również pojedyncze wnioski zgłaszane przez komisje stałe, w których postulowano nadanie uprawnień komisji śledczej własnej podkomisji, której skład odzwierciedlał parytet klubowy Sejmu. Pierwsze takie wnioski z żądaniem nadania im charakteru nagłego

${ }^{65}$ Ibidem, pos. 213. z 25 lutego 1921 r., 1. 48-79; pos. 214. z 1 marca 1921 r., ł. 22-24; pos. 218. z 11 marca 1921 r., ł. 79-83; pos. 224. z 15 kwietnia 1921 r., ł. 70-73; pos. 247. z 27 września 1921 r., ł. 23; pos. 248. z 30 września 1921 r., 1. 5-14; pos. 291. z 23 marca 1922 r., 1. 7-11.

${ }^{66}$ H. Pajdała, Komisje w parlamencie wspótczesnym, Warszawa 2001, s. 171-172; B. Banaszak, Sejmowa komisja śledcza jako forma sprawowania kontroli przez Sejm, „Przegląd Sejmowy” 2008, nr 3, s. 116; idem, Komisje śledcze we wspótczesnym parlamentaryzmie państw demokratycznych, Warszawa 2007, s. 60-67 i 121-123.

${ }^{67}$ Problematyka działalności komisji śledczych w SU nie znajdowała szerszego odzwierciedlenia w literaturze przedmiotu, a jeśli już to była traktowana pobieżnie i z licznymi błędami. Najczęściej zdarzało się błędne kwalifikowanie niektórych sejmowych komisji specjalnych lub podkomisji do grona śledczych, podczas gdy ich zadania nierzadko miały charakter wspierający dla administracji rządowej oraz Sejmu i nie wiązały się $\mathrm{z}$ badaniem zarzutów stawianych egzekutywie oraz podległym jej organom i strukturom. W literaturze nie podejmowano w ogóle zagadnień proceduralnych funkcjonowania komisji śledczych; confer M. Pietrzak, Rzady..., s. 281-283; A.J. Madera, Sejmowe komisje śledcze. Studium prawno-historyczne, Kraków-Rzeszów 2008, s. 77-78; idem, Sejmowe komisje śledcze. Polskie tradycje i doświadczenia współczesne, Toruń 2011, s. 29-30. 
wpłynęły do laski marszałkowskiej już w marcu 1919 r. i zostały odesłane przez izbę na wniosek marszałka do Komisji Administracyjnej ${ }^{68}$.

Istotny z punktu widzenia odtworzenia pełnej procedury sejmowej z udziałem komisji śledczej był wniosek o powołanie takowej wywołany interpelacją zgłoszoną 10 kwietnia 1919 r. przez posłów Nojacha Priłuckiego i Izaaka Grünbauma oraz towarzyszy w sprawie tragedii w Pińsku z 5 kwietnia 1919 r., polegającej na rozstrzelaniu przez wojsko kilkudziesięciu mieszkańców miasta narodowości żydowskiej. Po odpowiedzi ministra spraw wojskowych na interpelację marszałek Sejmu przedstawił wniosek podpisany przez posłów żydowskich, wspartych przez posłów polskich z klubów lewicowych, o powołanie złożonej z 10 posłów komisji specjalnej z udziałem dwóch posłów żydowskich dla zbadania na miejscu przebiegu zdarzeń w Pińsku. Sejm przyjął wniosek jednomyślnie i powierzył wykonanie uchwały, czyli wyłonienie składu komisji specjalnej, Komisji Prawniczej izby. Komisja poprosiła większe kluby poselskie o przedstawienie kandydatur do komisji śledczej. Czynności komisji w sprawie pińskiej trwały ponad dwa lata, bowiem ostateczne sprawozdanie ze swych prac złożyła ona izbie dopiero 24 maja $1921 \mathrm{r}$. Komisja potwierdziła w większości zarzuty podniesione w interpelacji posłów żydowskich i przedstawiła rezolucję pod adresem rządu żądającą postawienia przed sądem wojskowym sprawców egzekucji i innych represji wojskowych jej towarzyszących, zwrotu nałożonej na ludność żydowską miasta kontrybucji oraz wypłaty odszkodowania rodzinom niewinnie rozstrzelanych. Sejm przyjął tę rezolucję ${ }^{69}$.

Postępowanie w sprawie wyłonienia komisji śledczej w sprawie pińskiej oraz jej czynności stały się precedensem, który stosunkowo szybko doprowadził do wykształcenia się zwyczajowej procedury postępowania kontrolnego z udziałem komisji śledczej. Zasadniczymi cechami tej procedury były: zgłoszenie na plenum Sejmu wniosku podpisanego przez co najmniej 15 posłów; nadanie mu przez izbę klauzuli nagłości po krótkiej dyskusji (niekiedy jednak wniosek stawiał sam marszałek); uchwalenie meritum wniosku; odesłanie przez marszałka wniosku do Komisji Prawniczej Sejmu; skompletowanie przez Komisję Prawniczą składu osobowego komisji śledczej (liczącego zależnie od treści wniosku od trzech do dziewięciu posłów) na podstawie zgłoszeń klubów sejmowych; ukonstytuowanie się komisji śledczej i przyjęcie przez nią harmonogramu prac i podziału czynności; czynności terenowe komisji in gremio bądź przez upoważnionych członków; przygotowanie przez przewodniczącego komisji sprawozdania z załączonymi rezolucjami dla plenum (najczęściej ustnego, ale zdarzały się również drukowane); wygłoszenie sprawozdania na plenum izby i głosowanie nad rezolucją (rezolucjami) końcową bądź jej przyjęcie (najczęściej) tacite. Od przedstawionego schematu zdarzały się częściowe odstępstwa polegające, np. na: odsyłaniu wniosku uchwalonego na plenum nie do Komisji Prawniczej, lecz do Komisji Administracyjnej, co miało już swoje precedensy w pierwszych tygodniach konstytuanty; uzupełnieniu

${ }^{68}$ Sejm Ustawodawczy RP, druk nr 145; spr. sten. SU, pos. 13. z 11 marca 1919 r., 1. 675-679; pos. 14. z 14 marca 1919 r., ł. 775.

${ }^{69}$ Spr. sten. SU, pos. 29. z 10 kwietnia 1919 r., 1. 61-65; pos. 30. z 11 kwietnia 1919 r., ł. 47; pos. 61. z 2 lipca 1919 r., 1. 3-4; pos. 229. z 24 maja 1921 r., ł. 46-48; Sejm Ustawodawczy RP, druk nr 1856. 
składu komisji o urzędników delegowanych przez zainteresowane ministerstwa; rozszerzeniu kompetencji komisji o prawo składania wniosków do właściwych władz administracyjnych, cywilnych i wojskowych oraz sądowych; składaniu sprawozdania cząstkowego z prac komisji, które poprzedzało o kilka miesięcy sprawozdanie końcowe. Jednak zdarzały się przypadki, że prace komisji śledczej nie znajdowały finalizacji w postaci sprawozdania na plenum i przyjęcia stosownych rezolucji końcowych ${ }^{70}$.

\section{POSTĘPOWANIA W RAMACH FUNKCJI KREACYJNEJ W ŚWIETLE PRAWA POZYTYWNEGO I PRAKTYKI PARLAMENTARNEJ}

W ramach funkcji kreacyjnej SU dokonywał obsady swych organów wewnętrznych ${ }^{71}$ oraz wskazanych ustawą organów państwowych. Podstawę normatywną procedury wyborczej stanowiły odnośne przepisy regulaminu. Spośród organów wewnętrznych izba dokonywała wyboru marszałka, pięciu jego zastępców (wicemarszałków), ośmiu sekretarzy (od 21 października 1919 r. dziewięciu), sześciu kwestorów oraz składu osobowego komisji stałych. Marszałek był wybierany bezwzględną większością głosów posłów obecnych na posiedzeniu, w głosowaniu tajnym. Jeśli pierwsze głosowanie nie dało rezultatu, w drugim wybierano spośród pięciu kandydatów, którzy otrzymali największą liczbę głosów. Niedokonanie wyboru prowadziło do trzeciego głosowania, w którym marszałka wybierano spośród dwóch kandydatów, którzy otrzymali największą liczbę głosów w drugiej rundzie. W razie równości głosów rozstrzygać miało losowanie. Głosy posłów wstrzymujących się (oddających „,białe kartki”) nie były brane pod uwagę (art. 7 regulaminu). Regulamin Sejmu, poza postanowieniem o głosowaniu tajnym, nie zawierał dokładnych przepisów określających tryb wyboru zastępców marszałka i sekretarzy (art. 8), co oznaczało, że deficyt ten izba musiała przezwyciężyć w drodze praktyki. Należało przypuszczać, że Sejm stosowałby odpowiednio przepisy dotyczące wyboru marszałka, ale praktyka (o czym niżej) przyjęła tu procedurę uzgadniania kandydatur na posiedzeniu Konwentu Seniorów i ich akceptacji na plenum w drodze aklamacji. Instytucja kwestorów miała charakter pozaregulaminowy i zapożyczono ją z parlamentaryzmu zachodnioeuropejskiego. Ich celem było kontrolowanie rachunków parlamentu. Odnośnie do wyłaniania składu osobowego komisji sejmowych (tzw. wielkich, liczących początkowo 30, a od 9 lipca 1919 r. - 31 członków oraz małych, liczących 15 posłów) regulamin postanawiał, że miało się to odbywać „wedle klucza, odpowiadającego sile liczebnej grup poselskich" (art. $49 \mathrm{zd}$. 2).

Wyboru marszałka SU dokonywał dwukrotnie. Pierwszy raz na drugim posiedzeniu plenarnym 14 lutego 1919 r., kiedy to odbyły się dwie tury głosowania, które

${ }^{70}$ Spr. sten. SU, pos. 38. z 15 maja 1919 r., 1. 31-37; pos. 42. z 27 maja 1919 r., 1. 65-66; pos. 66. z 9 lipca 1919 r., ł. 4-23; pos. 96. z 7 listopada 1919 r., 1. 14-17; pos. 102. z 21 listopada 1919 r., 1. 4-23; pos. 104. z 27 listopada 1919 r., ł. 32; pos. 127. z 5 marca 1920 r., ł. 45-69; pos. 136. z 26 marca 1920 r., ł. 52-54; pos. 160. z 8 lipca 1920 r., ł. 50-55; pos. 232. z 7 czerwca 1921 r., ł. 66-68; pos. 242. z 8 lipca 1921 r., ł. 85-87; pos. 325. z 6 lipca 1922 r., 1. 49-55; pos. 326. z 7 lipca 1922 r., ł. 59-64; Sejm Ustawodawczy RP, druk nr 576; nr 1650.

${ }^{71}$ Vide szerzej na temat wyłaniania organów wewnętrznych SU P.A. Tusiński, Norma prawna..., s. $70-75$. 
doprowadziły do wyboru na to stanowisko prawnika, byłego posła do Reichstagu Rzeszy Niemieckiej, Wojciecha Trąmpczyńskiego. Trąmpczyński miał dwóch kontrkandydatów — Wincentego Witosa z PSL „Piast” oraz Józefa Ostachowskiego z Polskiego Zjednoczenia Ludowego. Posłowie głosowali kartkami, wywoływani imiennie do urny przez tymczasowego sekretarza, a głosy obliczała wyłoniona spośród nich komisja skrutacyjna. Po ogłoszeniu wyniku głosowania marszałek-senior zapytał elekta, czy przyjmuje wybór. Po potwierdzeniu, wybrany niezwłocznie objął urząd i wygłosił krótkie przemówienie ${ }^{72}$. Drugi raz wybory marszałka konstytuanty odbyły się 5 czerwca 1919 r., po wyborach sejmowych w Poznańskiem. Kontrkandydatem Trąmpczyńskiego był Błażej Stolarski z PSL „Wyzwolenie”. Dotychczasowy marszałek wygrał je zdecydowanie w pierwszej rundzie ${ }^{73}$. Wybór wicemarszałków oraz sekretarzy dokonał się przez aklamację na drugim posiedzeniu izby, w następstwie uzgodnień poczynionych na posiedzeniu Konwentu Seniorów przez kluby poselskie w nim reprezentowane, czyli liczące co najmniej 12 członków $^{74}$. Należy zaznaczyć, że funkcje sekretarzy obsadzili najmłodsi wiekiem posłowie klubów je delegujących, co stało się zwyczajem kontynuowanym w całym dwudziestoleciu międzywojennym. Wyboru kwestorów izba dokonała na wniosek Konwentu Seniorów na trzecim posiedzeniu plenarnym przez aklamację, przy czym liczba sześciu kwestorów wynikała z ówczesnej struktury frakcyjnej Sejmu, obejmującej tyleż klubów ${ }^{75}$.

Proces powoływania komisji stałych SU przebiegał na przestrzeni dwóch pierwszych lat jego pracy. W okresie tym powołano 28 komisji ,wielkich” i „,małych” (w tym złożoną z siedmiu członków Komisję Kontroli Długów Państwa). Ponadto izba wyłoniła na przestrzeni całego okresu swej działalności 21 komisji specjalnych (w tym trzy formalnie były podkomisjami; w tej liczbie mieściły się wzmiankowane wyżej komisje śledcze) ${ }^{76}$. Składy osobowe wszystkich komisji sejmowych okresu konstytuanty były obsadzane na podstawie zasady proporcjonalności Victora d'Hondta. Liczbę miejsc przypadających poszczególnym frakcjom poselskim (ale też parytet obsady prezydiów komisji) ustalano $\mathrm{w}$ zależności od ich liczebności, ale z uprawnienia tego korzystały wyłącznie kluby reprezentowane w Konwencie Seniorów, czyli liczące co najmniej 12 posłów ${ }^{77}$.

72 Spr. sten. SU, pos. 2. z 14 lutego 1919 r., ł. 32-35. Wybór Trąmpczyńskiego został poprzedzony poufnymi uzgodnieniami między kilkoma większymi klubami poselskimi, co stało się zwyczajem stosowanym do końca lat dwudziestych; A. Ajnenkiel, Sejm jako czynnik integracji narodu i państwa, [w:] Sejmy Drugiej Rzeczypospolitej, red. A. Zakrzewski, Warszawa 1990, s. 29.

${ }_{73}$ Spr. sten. SU, pos. 46. z 5 czerwca 1919 r., 1. 3-4.

74 Ibidem, pos. 2. z 14 lutego 1919 r., ł. 35-37. W trakcie prac Sejmu nastąpiły dwie zmiany na stanowisku wicemarszałka; pos. 59. z 30 czerwca 1919 r., ł. 4; pos. 90 . z 21 października 1919 r., ł. 4.

${ }^{75}$ Ibidem, pos. 3. z 20 lutego 1919 r., 1. 90-91.

${ }^{76}$ Vide A. Tomaszewska, Aneksy, [w:] A. Ajnenkiel, Historia Sejmu polskiego, t. II, cz. II: II Rzeczpospolita, Warszawa 1989, s. 283-284.

${ }^{77}$ L. Zieleniewski, Regulamin Senatu na tle regulaminów i praktyki izb ustawodawczych w Polsce i innych państwach, t. II, Warszawa 1933, s. 22-23 i 30; J. Dębski, Wspomnienia, mps Ossolineum, sygn. 15354/II, s. 181, 646. Praktykę tę zapowiedział marszałek Trąmpczyński: „Obsadzenie tych komisyj odbędzie się według klucza, odpowiadającego sile liczebnej grup, które potem tylko biuru sejmowemu doniosą, kogo do komisji delegują [...] Wybór komisji odbędzie się poza plecami plenum w ten sposób, że każda grupa doniesie kogo deleguje do komisji i ci delegaci automatycznie staną się członkami komisji”; spr. sten. SU, pos. 2. z 14 lutego 1919 r., 1.37 i 47. 
Na marginesie tej kwestii należy zaznaczyć, że układ polityczny w konstytuancie był niestabilny, ponieważ częstym zjawiskiem były rozłamy i fuzje klubów, a także „wędrówki" posłów między frakcjami, co wywoływało fluktuację składów komisji. Praktyka parlamentarna tego okresu dopracowała się ponadto zwyczajowej instytucji zastępcy członka komisji (niekiedy stałego, ale zazwyczaj pro tempore ${ }^{78}$.

Sejm Ustawodawczy od 1920 r. realizował obsadzanie składów osobowych różnych organów państwowych na podstawie regulacji ustawowych. W sytuacji braku wyraźnej normy regulaminowej w sprawie przebiegu takich wyborów należało sądzić, że izba powinna była dla ich przeprowadzania stosować odpowiednio przepisy dotyczące wyboru marszałka (głosowanie tajne kartkami, z zastosowaniem trzech tur elekcji) ${ }^{79}$. Praktyka parlamentarna przyjęła w tym względzie jednak różne formy wyboru: zasadę aklamacji, podobnie jak w odniesieniu do obsady stanowisk wicemarszałków, kwestorów i sekretarzy; zasadę głosowania kartkami oraz zasadę głosowania przez powstanie z miejsc. Według reguły aklamacji konstytuanta dokonała, zgodnie z wnioskami zawartymi w sprawozdaniach odpowiednich komisji, wyboru członków i zastępców członków Tymczasowego Wydziału Samorządowego w byłej Galicji (spoza swojego składu, na wniosek rządu) ${ }^{80}$ oraz Rady Obrony Państwa z ramienia Sejmu ${ }^{81}$, a także ośmiu przedstawicieli Sejmu w Państwowej Radzie Emigracyjnej (utworzonej na podstawie uchwały Rady Ministrów ${ }^{82}$. Na zasadzie głosowania kartkami wybrano członków Głównej Komisji Ziemskiej ${ }^{83}$. Poprzez powstanie z miejsc dokonano wyboru, na wniosek większości Komisji Przemysłowo-Handlowej, dwóch spośród sześciu członków Komitetu Dyrekcyjnego Pocztowej Kasy Oszczędności ${ }^{84}$.

\section{POSTĘPOWANIA W SPRAWACH OKOLO IMMUNITETOWYCH W ŚWIETLE PRAWA POZYTYWNEGO I PRAKTYKI PARLAMENTARNEJ}

Wcześniej zaznaczono, że do grupy tych procedur należy zaliczyć postępowania w kwestiach: ważności mandatu poselskiego, interwencji w zakresie naruszenia nietykalności poselskiej przez organy administracji, wyrażenia zgody na uchylenie immunitetu poselskiego (formalnego) oraz odnoszące się do egzekwowania odpowiedzialności pozaimmunitetowej posłów.

${ }^{78}$ Wspomina o tym zwyczaju zasiadający w ławach sejmowych w następnej kadencji poseł S. Rymar: „Jakkolwiek każdy klub delegował imiennie i na stałe swoich posłów [...] do wyznaczonej komisji, istniał przejęty już z pierwszego Sejmu zwyczaj, iż każdy inny członek tego klubu mógł zastępować swojego klubowego kolegę, za niego przemawiać i głosować. Wystarczyło, by się tego dnia wpisał na listę obecnych"; Pamiętnik. cz. II: W Polsce zjednoczonej, mps w Bibliotece Jagiellońskiej w Krakowie, sygn. 9797/III, s. 288.

79 Vide wystąpienie sprawozdawcy Komisji Administracyjnej Sejmu, W. Kiernika; spr. sten. SU, pos. 136. z 26 marca 1920 r., ł. 6.

${ }^{80}$ Ibidem, 1. 5-7; pos. 144. z 4 maja 1920 r., 1. 17; pos. 256. z 21 października 1921 r., 1. 27; pos. 291. z 23 marca 1922 r., 1. 6-7.

${ }^{81}$ Ibidem, pos. 157. z 1 lipca 1920 r., ł. 27-28; pos. 166. z 24 lipca 1920 r., ł. 6.

82 Ibidem, pos. 248. z 30 września 1921 r., 1. 4-5.

83 Ibidem, pos. 177. z 22 października 1920 r., 1. 32-39; pos. 178 . z 26 października 1920 r., 1. 67.

${ }^{84}$ Ibidem, pos. 208. z 10 lutego 1921 r., 1. 5-7. 
Kwestia ważności mandatu poselskiego była rozpatrywana na posiedzeniu plenarnym SU tylko jeden raz, w początkach jego pracy. Sprawa dotyczyła posła Nojacha Priłuckiego, którego mandat zakwestionował poseł Narodowej Demokracji Stefan Rottermund. Marszałek odesłał sprawę do Komisji Regulaminowej i Nietykalności Poselskiej, która w sprawozdaniu na posiedzeniu plenarnym wnioskowała o przekazanie Sądowi Najwyższemu zbadania ważności mandatu w trybie art. 96 dekretu o ordynacji wyborczej ${ }^{85}$. Ponieważ sprawa należała do jurysdykcji sądu, dyskusja nie mogła zasadniczo dotyczyć kwestii natury merytorycznej, lecz wyłącznie aspektów proceduralnych. Po jej odbyciu izba zdecydowała się poprzeć większością głosów wniosek komisji. Sąd Najwyższy uznał zasadność zarzutu nieważności mandatu poselskiego, a Priłuckij jako nieposiadający obywatelstwa polskiego w chwili wyboru utracił miejsce w ławach sejmowych ${ }^{86}$.

Sprawy zarzutów kierowanych pod adresem organów administracji rządowej o naruszenie nietykalności poselskiej były wielokrotnie poruszane w SU. Zasadniczo postępowania w takich sprawach były inicjowane przez posłów za pomocą instytucji wniosku nagłego lub oświadczenia na posiedzeniu plenarnym. W ich następstwie marszałek kierował sprawę do Komisji Regulaminowej i Nietykalności Poselskiej (w jej obradach udział brał minister lub inny przedstawiciel Ministerstwa Spraw Wewnętrznych w celu składania wyjaśnień), a następnie przedstawiał jej sprawozdanie na posiedzeniu plenarnym. Komisja kończyła sprawozdanie wnioskiem o uchwalenie stosownej rezolucji uznającej wyjaśnienia resortu, że do naruszenia nietykalności (scil. immunitetu formalnego) nie doszło ${ }^{87}$ bądź wzywającej rząd do ukarania winnych naruszenia immunitetu i złożenia w tej sprawie sprawozdania Sejmowi ${ }^{88}$. Zdarzało się jednak, że marszałek po oświadczeniu posła nie kierował sprawy do komisji, lecz zobowiązywał się sam zainteresować nią ministra spraw wewnętrznych ${ }^{89}$. Niekiedy też sprawy naruszenia nietykalności poselskiej były procedowane $\mathrm{w}$ trybie postępowania interpelacyjnego ${ }^{90}$.

Zdecydowanie najczęściej sprawy immunitetowe były rozpatrywane na forum konstytuanty z powodu wniosków ministra sprawiedliwości (występującego w imieniu sądu rozpoznającego wniosek z oskarżenia prywatnego bądź w imieniu prokuratora działającego w charakterze oskarżyciela publicznego) o zgodę na ściganie posła w trybie postępowania karnego (o uchylenie immunitetu poselskiego), zgłaszanych na podstawie stosownych przepisów ustawy z dnia 8 kwietnia 1919 r. o nietykalności posłów Sejmu Ustawodawczego ${ }^{91}$. Tryb postępowania w takich sprawach odpowiadał cechom regulaminowym ogólnego postępowania wnioskowego i był następujący: wpłynięcie wniosku ministra do marszałka Sejmu; przekazanie wniosku przez marszałka do Komisji Regulaminowej i Nietykalności Poselskiej; sprawozdanie komisji na posiedzeniu plenarnym

${ }^{85}$ Dz.P.P.P. nr 18, poz. 46.

${ }^{86}$ Spr. sten. SU, pos. 22. z 31 marca 1919 r., 1. 3-17; Kto byt kim..., s. 404.

87 Ibidem, pos. 28. z 8 kwietnia 1919 r., 1. 17-19; pos. 59 . z 30 czerwca 1919 r., 1. 4-15.

${ }^{88}$ Ibidem, pos. 80. z 29 lipca 1919 r., 1. 41-42; pos. 280. z 24 stycznia 1922 r., 1. 39-44.

${ }^{89}$ Ibidem, pos. 145 . z 7 maja 1920 r., 1. 4; pos. 317. z 8 czerwca 1922 r., ł. 3-4.

${ }^{90}$ Ibidem, pos. 180. z 29 października 1920 r., 1. 3; pos. 222. z 18 marca 1921 r., 1. 34-42; pos. 223. z 14 kwietnia 1921 r., $1.53-54$.

${ }_{91}$ Dz.U.R.P. nr 31, poz. 263. 
(najczęściej ustne), zakończone wnioskiem o wyrażenie zgody na ściganie bądź o odmowę zgody; ewentualna dyskusja; przyjęcie wniosku komisji tacite lub w drodze głosowania „przez powstanie z miejsc”.

Pierwszy wniosek ministra sprawiedliwości o uchylenie immunitetu posłowi SU wpłynął do laski marszałkowskiej niebawem po wejściu w życie powołanej ustawy. Izba, zgodnie z postulatem komisji, wniosek o ściganie oddaliła na posiedzeniu 30 czerwca 1919 r. ${ }^{92} \mathrm{~W}$ sumie do Sejmu wpłynęło 56 wniosków o uchylenie immunitetu poselskiego, ale tylko ośmiokrotnie izba przychylała się do wniosków ministra sprawiedliwości ${ }^{93}$. Stało się tak czterokrotnie w odniesieniu do komunizującego posła Tomasza Dąbala (którego dotyczyło aż siedem wniosków) ${ }^{94}$, trzykrotnie w stosunku do lewicowego radykała, ks. Eugeniusza Okonia (cztery wnioski) ${ }^{95} \mathrm{i}$ jeden raz wobec socjalistycznego posła Jerzego Kantora ${ }^{96}$. Trzy razy zdarzyło się, że większość izby nie przychyliła się do wniosku komisji rekomendującego wydanie posła sądowi ${ }^{97}$. Niekiedy Sejm wyrażał zgodę na uchylenie immunitetu na życzenie posła, który chciał się oczyścić przed sądem ze stawianych mu zarzutów ${ }^{98}$, jakkolwiek nie było to sztywną regułą ${ }^{99}$, bądź też przychylał się do wniosku komisji o zawieszenie toczącego się przeciw posłowi postępowania karnego z oskarżenia prywatnego, wszczętego przed objęciem mandatu poselskiego ${ }^{100}$.

Wspomniana ustawa o nietykalności posłów SU, zakreślając szeroko poselski immunitet materialny i formalny, utrudniała pociąganie członków izby do odpowiedzialności za wystąpienia — zarówno na forum parlamentu, jak i poza nim — godzące w powagę przedstawicielstwa narodowego oraz naruszające dobre imię osób trzecich. W tej

${ }^{92}$ Spr. sten. SU, pos. 59. z 30 czerwca 1919 r., ł. 15-16.

${ }_{93}$ Sprawozdawca komisji, poseł Z. Seyda, na jednym z posiedzeń izby stwierdził, że trzyma się komisja w takich sprawach ,przyjętej zasady, że jedynie w tych wypadkach, w których zachodzi jaskrawe jakieś naruszenie porządku publicznego obrażającego ogólne poczucie sprawiedliwości, należy z tej możliwości [czyli wydania posła sądowi - uwaga P.A.T.] skorzystać" (spr. sten. SU, pos. 146. z 11 maja 1920 r., ł. 65). W innym miejscu uzupełniał, że chodzi o ,zarzut jakiejś pospolitej zbrodni, o zarzut taki, który w oczach każdego [...] uczciwie myślącego człowieka jest w stanie podać w pogardę danego posła, jak też zachwiać zaufanie do całości instytucji Sejmu" i dodawał kolejną regułę, że: komisji nie przysługuje ,prawo badania winy posła [...] Komisja [bowiem] nie jest sądem. Sejmowi w całości również nie przysługuje prawo pełnienia funkcji sądu i dlatego winna komisja i winien Sejm [...] ograniczać się wyłącznie do stwierdzeń, czy rodzaj przestępstwa jest taki, że należy odstąpić od ogólnej zasady, że postępowania karne przeciw posłom nie mają być przeprowadzone"; pos. 184. z 11 listopada 1920 r., 1. 6-7.

${ }^{94}$ Spr. sten. SU, pos. 184. z 11 listopada 1920 r., $1.11-35$; pos. 211 . z 18 lutego 1921 r., 1. 10-17; pos. 262. z 18 listopada 1921 r., 1. 18-36; pos. 335. z 5 sierpnia 1922 r., ł. 30-37.

95 Ibidem, pos. 184. z 11 listopada 1920 r., ł. 35-36; pos. 262. z 18 listopada 1921 r., ł. 8-17; pos. 277. z 13 stycznia 1922 r., 1. 7-11.

${ }^{96}$ Ibidem, pos. 238. z 23 czerwca 1921 r., 1. 45-46.

${ }_{97}$ Ibidem, pos. 210. z 15 lutego 1921 r., ł. 11-15; pos. 262. z 18 listopada 1921 r., 1. 4-8; pos. 335. z 5 sierpnia 1922 r., 1. 6-8 i 36-37.

${ }_{98}$ Ibidem, pos. 145. z 7 maja 1920 r., 1. 63-66; pos. 161. z 9 lipca 1920 r., ł. 28-30; pos. 211. z 18 lutego 1921 r., 1. 9-10.

${ }_{99} \mathrm{~Np}$. w sprawie posła K. Wysockiego komisja wnioskowała, a izba to uwzględniła (wbrew woli posła), aby uchylić mu immunitet, o odmowę zgody na postępowanie karne z oskarżenia prywatnego; spr. sten. SU, pos. 184. z 11 listopada 1920 r., 1. 5-9.

${ }^{100}$ Ibidem, pos. 189. z 25 listopada 1920 r., ł. 40. 
sytuacji nierzadko jedynym sposobem powściągania tego typu zachowań była instytucja odpowiedzialności dyscyplinarnej posłów. Normy prawa pozytywnego (regulaminowe) oraz zwyczajowego obowiązujące w pierwszym parlamencie odrodzonej RP przewidywały dwa tryby odpowiedzialności dyscyplinarnej posłów. Pierwszy obejmował odpowiedzialność egzekwowaną przez marszałka izby, w trybie władczym, jednostronnym (art. 58-61 regulaminu). Odpowiedzialność ta była codziennością w pracach izby i nie miała zasadniczych związków z instytucją immunitetu, za którym w znaczącym stopniu mógł się ukryć poseł naruszający słowem lub czynem godność innej osoby lub dopuszczający się zachowań kwalifikowanych jako delikty prawne. W związku z powyższym pozostanie ona poza obszarem zainteresowania niniejszego opracowania. Drugi rodzaj odpowiedzialności dyscyplinarnej posłów obejmował odpowiedzialność o cechach kontradyktoryjnych, egzekwowaną przez wewnątrzizbowe organy quasi-sądowe — sąd marszałkowski oraz sąd honorowy. Ten rodzaj odpowiedzialności oparty był zrazu na normach prawa zwyczajowego, by od 25 listopada 1921 r. znaleźć częściowe umocowanie w normach regulaminowych. Obydwa rodzaje sądów były swoistymi i bezprecedensowymi na skalę światową parlamentarnymi substytutami powszechnych form odpowiedzialności obywateli za czyny niewyczerpujące znamion przestępstwa, lecz uchodzące za naruszenie etyki środowiskowej lub posiadające cechy deliktów prawa prywatnego ${ }^{101}$.

Jako pierwszy, w marcu 1920 r., pojawił się w konstytuancie sąd marszałkowski, ujmowany przez przewodniczącego izby jako instytucja o charakterze koleżeńskim, a przez doktrynę postrzegany przede wszystkim jako organ o charakterze dyscyplinarnym (wymierzający kary dyscyplinarne przypisane regulaminem do kompetencji marszałka). Swą nazwę wziął od składu, w którym zasiadali marszałek Sejmu jako przewodniczący oraz wszyscy obecni w czasie postępowania w Warszawie wicemarszałkowie izby. Zasadami działania sądu marszałkowskiego były: kolegialność, stałość składu (do 25 listopada 1921 r.), akuzacyjność, obok której występowały elementy oficjalności i inkwizycyjności, ograniczony formalizm procesowy, kontradyktoryjność, równość stron, bezpośredniość, niejawność, ustność, czynny udział stron w trakcie przewodu sądowego (z udziałem pełnomocników stron), dyspozytywność, swobodna ocena dowodów przez sąd, brak związania sądu zakresem żądań stron i dowodów przez nie dostarczonych, wyrokowanie większością głosów, stosowanie kar dyscyplinarnych, publikowanie wyroków, możliwość wniesienia apelacji od wyroku do plenum Sejmu. Z chwilą nowelizacji regulaminu Sejmu, dokonanej 25 listopada 1921 r., instytucja sądu marszałkowskiego została zastąpiona, ale tylko formalnie, gdyż w sensie materialnym sąd ten działał dalej — obok nowo powołanego i pod jego nazwą — jako sąd honorowy. W okresie od marca 1920 r. do listopada 1922 r. sąd marszałkowski przeprowadził pięć przewodów i wydał takąż liczbę wyroków, działając we wszystkich sprawach ze skargi posłów

${ }^{101}$ Na temat źródeł prawa, ustroju, procedur działania oraz praktyki funkcjonowania obu sądów, a także podstaw źródłowych i umocowania literaturowego poczynionych ustaleń vide P.A. Tusiński, Sąy honorowe i marszatkowskie w Sejmie i w Senacie II Rzeczypospolitej, „Przegląd Sejmowy” 2001, nr 5, s. 45-69. 
broniących swego dobrego imienia zaczepionego przez innych posłów bądź — jak w ostatniej sprawie - przez osobę spoza składu parlamentu (prokuratora w czasie rozprawy w sądzie powszechnym przeciw innemu posłowi, któremu izba uchyliła immunitet).

Pod koniec trzeciego roku obrad SU, 25 listopada 1921 r., izba dokonała uzupełnienia swego regulaminu powołując do życia instytucję sądu honorowego (art. 66). Tekst noweli nie zachował się, wobec czego o treści unormowań w nim zawartych można wnosić na podstawie przepisów Regulaminu Obrad Senatu z 1923 r. ${ }^{102}$ Przepisy senackie, poza niektórymi ujęciami szczegółowymi, były identyczne, jak obowiązujące w SU od listopada $1921 \mathrm{r}^{103} \mathrm{~W}$ ich świetle sąd honorowy był właściwy we wszystkich sprawach, „w których cześć posła została zakwestionowana”, a więc gdy obraził go drugi członek izby, jak i osoba spoza składu Sejmu. Ponieważ z chwilą swego pojawienia się sąd honorowy wchłonął wcześniejszy sąd marszałkowski, konstrukcja obu instytucji stała się identyczna, a różniła je jedynie procedura działania. Członkiem sądu honorowego, czyli kandydatem na arbitra lub superarbitra w składzie orzekającym, mógł być wicemarszałek izby lub poseł delegowany przez klub sejmowy. Członków sądu honorowego (kandydatów na arbitrów) delegowały po jednym kluby mające reprezentację w Konwencie Seniorów. Dopuszczalne było blokowanie się mniejszych klubów w celu wydelegowania wspólnego członka sądu. Członek sądu był nieusuwalny. W przypadku działania sądu honorowego jako marszałkowski, czyli w sprawie wszczętej z urzędu przez marszałka, możliwy był udział w postępowaniu zastępcy interesu publicznego, mianowanego przez marszałka spośród posłów. Skład orzekający sądu honorowego tworzyli dwaj arbitrzy i superarbiter jako przewodniczący. Arbitrów wskazywały spośród członków sądu strony postępowania w ciągu trzech dni od otrzymania wezwania ze strony marszałka. Brak wskazania uprawniał marszałka do wyznaczenia arbitra. Arbitrzy powołani do składu orzekającego mieli obowiązek ukonstytuowania sądu w ciągu 48 godzin od zakomunikowania im włączenia do składu, czyli dokonania wyboru superarbitra i powiadomienia o tym marszałka. Członkami składu orzekającego nie mogły być osoby związane ze stronami postępowania więzami rodzinnymi lub klubowymi, jak również w jakikolwiek sposób zainteresowane $\mathrm{w}$ danej sprawie bądź mogące wystąpić w przewodzie jako świadkowie. Postępowanie przed sądem miało cechy: kolegialności sądu, akuzacyjności, ograniczonego formalizmu procesowego, kontradyktoryjności, równości stron, bezpośredniości, niejawności, ustności, osobistego udziału stron (co wykluczało zastąpienie się pełnomocnikiem), dyspozytywności, związania sądu zakresem żądania stron oraz dostarczonym przez nie materiałem dowodowym ustalonym przez strony na pierwszym posiedzeniu sądu w postaci tzw. zapisu na sąd (zasada prawdy formalnej), swobodnej oceny dowodów, orzekania większością głosów z obowiązkiem uzasadnienia wyroku na piśmie, natychmiastowej mocy wyroku z chwilą jego ogłoszenia stronom, ostateczności oraz publikacji wyroku (poprzez ogłoszenie w czasie obrad plenarnych izby i odnotowanie treści w stenogramie), stosowania środków orzeczniczych charakterystycznych dla

102 Regulamin Obrad Senatu uchwalony dnia 24 marca 1923 r., Senat RP I kad., [brak numeru druku], art. 86-96.

103 L. Zieleniewski, op. cit., s. 87-88. 
sądów koleżeńskich i obywatelskich (mających znaczenie moralne w postaci potwierdzenia lub oddalenia zarzutów, z wykluczeniem użycia środków dyscyplinarnych stosowanych przed 25 listopada $1921 \mathrm{r}$. w sądzie marszałkowskim). Przepisy art. 66 regulaminu nie rozstrzygały o kosztach postępowania. O kwestii tej musiała zatem zdecydować praktyka. Sąd honorowy miał prawo — za pośrednictwem marszałka izby — żądać akt od instytucji pozaparlamentarnych, wzywać i przesłuchiwać świadków, powoływać rzeczoznawców, badać wszelkie dostarczone mu dokumenty, występować do sądów powszechnych o pomoc prawną w zakresie przesłuchania świadków. Strony w toku rozprawy miały prawo: zabierania głosu w celu wyjaśnienia lub sprostowania faktów, stawiania wniosków dowodowych i zadawania pytań osobom przesłuchiwanym przez sąd.

Od chwili pojawienia się aż do zakończenia działalności SU sąd honorowy wydał trzy wyroki. Posłużyły one obwinionym do skutecznego oczyszczenia się ze stawianych im na forum izby zarzutów, gdyż we wszystkich przewodach zapadły wyroki oddalające zarzuty. W jednej sprawie sąd ograniczył się tylko do stwierdzenia bezzasadności zarzutów, a w dwóch częściowo usprawiedliwił obwiniających działaniem bona fide, lecz z oparciem się na niesprawdzonych informacjach prasowych oraz uzyskanych od osób trzecich.

\section{UWAGI KOŃCOWE}

Pierwszy po latach niewoli narodowej parlament odrodzonej RP pełnił wszystkie klasyczne funkcje ustrojowe przypisane temu organowi władzy w systemie konstytucyjnym. Każda z nich niosła za sobą bogatą paletę szczegółowych procedur parlamentarnych, relatywnie słabo zakorzenionych (poza opisaną przez autora w innym miejscu procedurą ustawodawczą) $)^{104} \mathrm{~W}$ prawie pozytywnym, gros norm zawarte było w tymczasowym regulaminie obrad SU. Dla większości opisanych wcześniej procedur parlamentarnych bazę prawnopozytywną tworzyły przepisy regulaminowe normujące tzw. postępowanie wnioskowe (w sprawach wniosków składanych do laski marszałkowskiej przez wskazane podmioty inicjatywy wnioskodawczej). Poszczególne szczegółowe procedury parlamentarne były wyodrębnionymi instytucjonalnie wariantami postępowania wnioskowego. Konstatowany od początku prac Sejmu przez jej organy oraz zainteresowanych posłów deficyt reguł formalnoprawnych rodził konieczność implementacji zwyczajów parlamentarnych wykształconych $\mathrm{w}$ parlamentaryzmie zachodnioeuropejskim, a także dopracowania się rodzimych rozwiązań w toku praktyki. SU, dzięki m.in. dużemu zaangażowaniu posłów legitymujących się wiedzą prawniczą oraz doświadczeniem wyniesionym z organów przedstawicielskich państw zaborczych, poradził sobie z tym problemem w stopniu więcej niż zadowalającym. Dlatego też wiele szczegółowych rozwiązań proceduralnych wypracowanych $w$ okresie konstytuanty było kontynuowanych $w$ mniejszym lub większym zakresie w następnych kadencjach obu izb parlamentu II RP w systemie ustrojowym konstytucji marcowej aż do 1935 r., a niekiedy i dłużej. Na szczególne podkreślenie zasługują przede wszystkim rozwiązania proceduralne $\mathrm{w}$ ramach

104 P.A. Tusiński, Procedury..., passim. 
funkcji kontrolnej (zwłaszcza te dotyczące zagadnienia inwestytury parlamentarnej rządu, wotum nieufności oraz postępowania interpelacyjnego) oraz w sprawach około immunitetowych, z zagadnieniem egzekwowania odpowiedzialności pozaimmunitetowej parlamentarzystów w formach quasi-sądowych na czele. Forum sejmowe było szkołą kształtującej się polskiej kultury parlamentarnej, w której aspekty proceduralne ważyły znacząco na skuteczności i sprawności prac konstytuanty, a dokonania poczynione w tym zakresie mogą stanowić pole do odniesień porównawczych nie tylko o wartości historycznej.

\section{BIBLIOGRAFIA}

\section{ŹRÓDŁA}

Katalogi i bazy, Parlamentaria polskie 1919-1997, Sejm 1919-1939, Sejm Ustawodawczy 1919-1922, Interpelacje, <bs.sejm.gov.pl>.

Dębski J., Wspomnienia, mps w Bibliotece Zakładu Narodowego im. Ossolińskich we Wrocławiu, sygn. 15354/II.

„Dziennik Praw Królestwa Polskiego” 1918.

„Dziennik Praw Państwa Polskiego” 1918-1919.

„Dziennik Ustaw Rzeczypospolitej Polskiej” 1919-1921.

Exposé premierów polskich 1918-2001, oprac. B. Sygit, Wydawnictwo Zapolex Media, Toruń 2001.

„Kurier Polski” 1919-1922.

Nowak J., Wspomnienia z ławy rządowej, [b.o.w.], Kraków 1938.

Nowe konstytucje. Przełożone pod kierunkiem Dra Juliana Makowskiego, F. Hoesick, Warszawa 1925.

Rataj M., Pamiętniki, Ludowa Spółdzielnia Wydawnicza, Warszawa 1965.

Regulamin Obrad Senatu uchwalony dnia 24 marca 1923 r., Senat RP I kad., [brak numeru druku].

Rymar S., Pamiętnik, cz. II, W Polsce zjednoczonej, mps w Bibliotece Jagiellońskiej w Krakowie, sygn. 9797/III.

Sejm Ustawodawczy Rzeczypospolitej Polskiej 1919-1922, Druki.

Sejm Ustawodawczy Rzeczypospolitej Polskiej 1919-1922. Sprawozdania stenograficzne.

Tymczasowy Regulamin Obrad Sejmu Ustawodawczego Rzeczypospolitej Polskiej, oprac. T. Koperska, „Przegląd Sejmowy” 1993, nr 1.

Wojdaliński R., Relacje posła na Sejm Ustawodawczy (1919-1922), t. I-IV, mps Ossolineum, sygn.14108/II.

\section{PIŚMIENNICTWO}

Ajnenkiel A., Sejm jako czynnik integracji narodu i państwa, [w:] Sejmy Drugiej Rzeczypospolitej, red. A. Zakrzewski, Ludowa Spółdzielnia Wydawnicza, Warszawa 1990.

Badziak K., W oczekiwaniu na przełom. Na drodze od odrodzenia do załamania państwa polskiego listopad 1918-czerwiec 1920, Ludowa Spółdzielnia Wydawnicza, Łódź 2004.

Banaszak B., Komisje śledcze we współczesnym parlamentaryzmie państw demokratycznych, Wydawnictwo Sejmowe, Warszawa 2007.

Banaszak B., Prawo konstytucyjne, C.H. Beck, Warszawa 2012.

Banaszak B., Sejmowa komisja śledcza jako forma sprawowania kontroli przez Sejm, „Przegląd Sejmowy" 2008, nr 3. 
Banaszak B., Wotum nieufności, [w:] Encyklopedia prawa, red. U. Kalina-Prasznic, Wolters Kluwer, Warszawa 1999.

Faryś J., Konflikt Naczelnika Państwa z Sejmem Ustawodawczym w 1922 roku, „Dzieje Najnowsze" 1975, nr 3.

Gabinety Drugiej Rzeczypospolitej, red. J. Faryś, J. Pajewski, „Likon”, Szczecin-Poznań 1991.

Górecki D., Powstawanie władz naczelnych w odradzajacej się Polsce (1914-1919), „Acta Universitatis Lodziensis. Folia Iuridica" 1983, nr 13.

Gwiżdż A., Prawo interpelacji posła na Sejm PRL, „Państwo i Prawo” 1956, z. 11.

Gwiżdż A., Interpelacja i procedury podobne $w$ burżuazyjnym prawie państwowym, „Państwo i Prawo" 1963, z. 4.

Kaczmarek Z., Wojciech Trampczyński, Lega, Poznań 1993.

Kierończyk P., Nadrzędność parlamentu - mit czy realna alternatywa ustrojowa? Analiza wybranych przykładów, Gdańska Wyższa Szkoła Administracji, Gdańsk 2009.

Koksanowicz G., Prawnoustrojowa pozycja marszałka Sejmu w okresie II Rzeczypospolitej, „Przegląd Sejmowy” 2003, nr 2.

Komarnicki W., Polskie prawo polityczne (geneza i system), F. Hoesick, Warszawa 1922.

Krukowski S., Sejm Ustawodawczy 1919-1922. Uwagi o składzie i działalności, „Czasopismo Prawno-Historyczne" 1986, z. 1.

Kto byt kim w Drugiej Rzeczypospolitej, red. J.M. Majchrowski i in., Polska Oficyna Wydawnicza „BGW”, Warszawa 1994.

Kustra E., Proces ustawodawczy jako proces decyzyjny, „Acta Universitatis Nicolai Copernici, Nauki Humanistyczno-Społeczne, Prawo XII”, 1973, z. 56.

Lipska M.M., Urzad ministra w latach 1918-1939. Podstawy prawne, „Roczniki Nauk Prawnych" 2009, t. XIX, nr 1.

Madera A.J., Sejmowe komisje śledcze. Studium prawno-historyczne, Firma SAS Wanda Tarnawska, Kraków-Rzeszów 2008.

Madera A.J., Sejmowe komisje śledcze. Polskie tradycje i doświadczenia wspótczesne, Wydawnictwo Adam Marszałek, Toruń 2011.

Majkowski A., Uwagi ogólne o technice prac parlamentarnych, [b.o.w.], Warszawa 1937.

Mojak R., Instytucja prezydenta w polskim prawie konstytucyjnym w latach 1918-1935, cz. 1, „Annales Universitatis Mariae Curie Skłodowska. Sectio G” 1989, t. XXXVI, nr 19.

Pajdała H., Komisje w parlamencie współczesnym, Wydawnictwo Sejmowe, Warszawa 2001.

Pietrzak M., Rzady parlamentarne w Polsce w latach 1919-1926, „Książka i Wiedza”, Warszawa 1969.

Preisner A., Wotum nieufności, [w:] Słownik wiedzy o Sejmie, red. A. Preisner, Wydawnictwo Sejmowe, Warszawa 1995.

Próchnik A., Pierwsze piętnastolecie Polski niepodległej. Zarys dziejów politycznych, Wydawnictwa Szkolne i Pedagogiczne, Warszawa 1983.

Rzepecki T., Sejm Rzeczypospolitej Polskiej 1919 roku, Wielkopolska Księgarnia Nakładowa, Poznań 1920.

Słownik języka polskiego, t. II, L-P, PWN, Warszawa 1979.

Sokolewicz W., Odpowiedzialność parlamentarna Rząu RP (votum zaufania, votum nieufności, absolutorium), Biuro Studiów i Ekspertyz Kancelarii Sejmu, Warszawa 1993.

Stembrowicz J., Z problematyki głowy państwa w Polsce, „Kultura i Społeczeństwo” 1977, nr 2.

Szawłowski R., Najwyższe państwowe organy kontroli II Rzeczypospolitej, Wydawnictwo „von borowiecky”, Warszawa 2004.

Tomaszewska A., Aneksy, [w:] A. Ajnenkiel, Historia Sejmu polskiego, t. II, cz. II: II Rzeczpospolita, PWN, Warszawa 1989. 
Tusiński P.A., Norma prawna i obyczaj jako podstawa wyłaniania i funkcjonowania organów kierowniczych parlamentu II Rzeczypospolitej, „Prace Naukowe Politechniki Radomskiej im. Kazimierza Pułaskiego: Ekonomika” 1999, nr 1.

Tusiński P.A., Postępowanie ustawodawcze w Sejmie i w Senacie II Rzeczypospolitej 1919-1939. Prawo - zwyczaje - praktyka parlamentarna, Wydawnictwo Politechniki Radomskiej, Radom 2008.

Tusiński P.A., Komisja Spraw Zagranicznych Sejmu Ustawodawczego (1919-1922) jako podmiot polityki zagranicznej w pierwszych latach II Rzeczypospolitej, „Wschodni Rocznik Humanistyczny" 2015, t. XII.

Tusiński P.A., Procedury ustawodawcze w pierwszym Sejmie Odrodzonej Rzeczypospolitej Polskiej (1919-1922). Regulacja prawna i praktyka parlamentarna, „Przegląd Sejmowy” 2018, nr 6.

Tusiński P.A., Sąy honorowe i marszałkowskie w Sejmie i w Senacie II Rzeczypospolitej, „Przegląd Sejmowy" 2001, nr 5.

Wielka encyklopedia prawa, red. E. Smoktunowicz, „Prawo i Praktyka Gospodarcza”, Białystok-Warszawa 2000.

Winnicki Z.J., Rada Regencyjna Królestwa Polskiego i jej organy (1917-1918), Wydawnictwo „Wektory”, Wrocław 1991.

Witkowski Z., Prezydent Rzeczypospolitej Polskiej 1921-1935, „Studia Iuridica. Towarzystwo Naukowe w Toruniu" 1987, t. XVIII, z. 1.

Witkowski Z., Status ustrojowy Rady Ministrów w konstytucjach polskich okresu międzywojennego, [w:] Rada Ministrów. Organizacja i funkcjonowanie, red. A. Bałaban, Kantor Wydawniczy Zakamycze, Kraków 2002.

Wołpiuk W.J., Naczelnik Państwa 1918-1922. Przedprezydencka forma władzy państwowej, „Przegląd Sejmowy” 2005, nr 6.

Zaleśny J., Odpowiedzialność konstytucyjna w Drugiej Rzeczypospolitej, Elipsa, Warszawa 2003.

Zieleniewski L., Regulamin Senatu na tle regulaminów oraz praktyki izb ustawodawczych w Polsce i innych państwach, t. II, F. Hoesick, W. Łazarski, Warszawa 1933. 